\title{
Interlake variation and environmental controls of denitrification across different geographical scales
}

\author{
Antti Juhani Rissanen ${ }^{1,2, *}$, Marja Tiirola ${ }^{1}$, Susanna Hietanen ${ }^{3}$, Anne Ojala ${ }^{4}$ \\ ${ }^{1}$ Department of Biological and Environmental Science, University of Jyväskylä, Survontie 9, 40500 Jyväskylä, Finland \\ ${ }^{2}$ Lammi Biological Station, University of Helsinki, Pääjärventie 320, 16900 Lammi, Finland \\ ${ }^{3}$ Department of Environmental Sciences, University of Helsinki, PO Box 65 (Viikinkaari 1), 00014 University of Helsinki, Finland \\ ${ }^{4}$ Department of Environmental Sciences, University of Helsinki, Niemenkatu 73, 15140 Lahti, Finland
}

ABSTRACT: Denitrification in lakes significantly reduces the nitrogen $(\mathrm{N})$ load from land to oceans, but the factors controlling it remain poorly understood. Therefore, interlake variation of denitrification in sediments of small to medium-sized lakes (from 0.03 to $17.8 \mathrm{~km}^{2}$ ) was studied across different geographical scales. At the local scale, the denitrification rates and sediment microbial communities were studied in 4 boreal lakes in close proximity (within 20 $\mathrm{km}$ ) using the isotope pairing technique (IPT) and molecular methods. These local scale data were combined with previously published data on denitrification rates from 10 other European lakes to extend the analysis to the regional (boreal area) and continental (boreal and temperate areas) scales. Denitrification varied considerably among lakes, ranging from $\sim 50$ to $\sim 600, \sim 0$ to $\sim 600$ and $\sim 0$ to $\sim 12900 \mu \mathrm{mol} \mathrm{N} \mathrm{m}{ }^{-2} \mathrm{~d}^{-1}$ at the local, regional and continental scales, respectively. This variation was primarily due to nitrate availability. The structure of the denitrifier community studied at the local scale was independent of the denitrification rates but varied among lakes correlating with nitrate availability and sediment organic content. Removal of nitrate and total N load by denitrification was less efficient in boreal than in temperate lakes. In addition, a meta-analysis of published $\mathrm{N}$ mass balance data indicates that the total $\mathrm{N}$ retention (denitrification $+\mathrm{N}$ sedimentation) is less efficient in boreal than in temperate lakes. Anaerobic ammonium oxidation (anammox) was studied at the local scale but was not detected, although (based on molecular markers) several anammox genera were present in the sediments.

KEY WORDS: Denitrification $\cdot$ Lake $\cdot$ Sediment $\cdot$ nirK

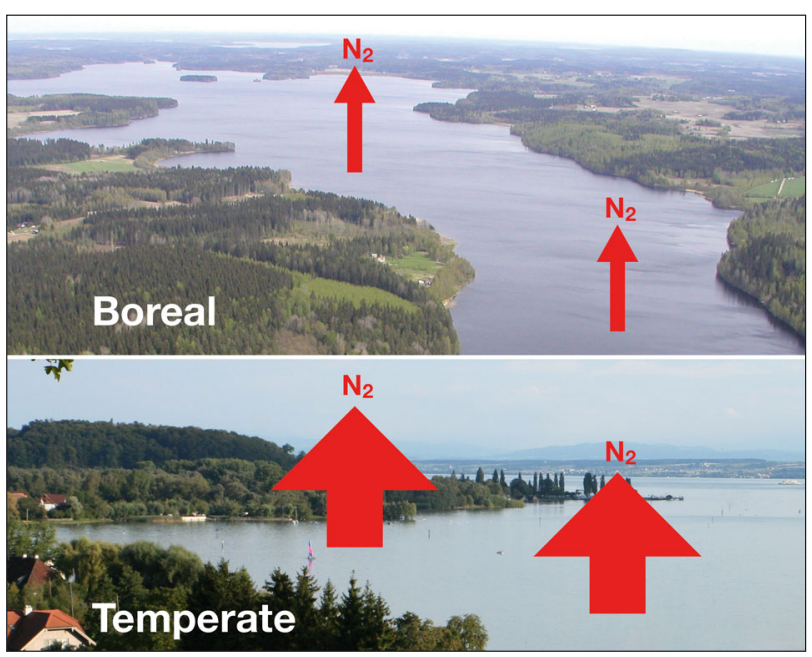

Removal of nitrate and total $\mathrm{N}$ load by denitrification was less efficient in boreal than in temperate lakes.

Photos: Ilpo Hakala (boreal) and Thyes (temperate)

\section{INTRODUCTION}

Lakes function as natural filters of excess nitrogen (N) load, significantly reducing the transport of $\mathrm{N}$ from land to coastal ecosystems (e.g. Lepistö et al. 2006, Seitzinger et al. 2006, Harrison et al. 2009). This takes place through sedimentation of organic $\mathrm{N}$ compounds and through microbially mediated emissions of $\mathrm{N}_{2}$ gas (Saunders \& Kalff 2001a), primarily through denitrification (e.g. Seitzinger 1988) but potentially also through anaerobic ammonium oxidation (anammox) (Schubert et al. 2006, Yoshinaga et al. 2011). Both processes mainly take place just 
below the oxic-anoxic interface of sediments. There, the processes are fed both by nitrate/nitrite diffusing to the anoxic zone from the overlying water and by nitrate/nitrite produced in the oxic surface zone by nitrification. Knowledge of the abiotic and biotic factors affecting $\mathrm{N}_{2}$ production over variable spatial scales is important in lake management, where one of the aims is to retain the $\mathrm{N}$ removal capacity of lakes.

Studies on single lakes have produced varying results in terms of the environmental factors affecting denitrification in lake sediments, such as temperature (Ahlgren et al. 1994, Saunders \& Kalff 2001b), nitrate concentration in the water above the sediment (e.g. Risgaard-Petersen et al. 1999, Rissanen et al. 2011) or the organic matter content of sediment (Saunders \& Kalff 2001b). Environmental controls differ between denitrification supported by nitrate from nitrification (coupled nitrification-denitrification [Dn]) and denitrification supported by nitrate from the overlying water ( $D$ w) (e.g. Cornwell et al. 1999). For instance, increasing temperature of the water overlying the sediment enhances nitrification, which in turn would support higher Dn (Berounsky \& Nixon 1990, Rysgaard et al. 1994, Bruesewitz et al. 2009), whereas $D$ w depends on the nitrate concentration in the water above the sediment (e.g. Rysgaard et al. 1994). In addition, the oxygen concentration of the water overlying the sediment affects the relative importance of $D \mathrm{n}$ and $D \mathrm{w}$ by controlling the thickness of the oxic sediment surface (e.g. Rysgaard et al. 1994). The variable results in single lake studies, therefore, reflect interlake differences in the dominance of $D \mathrm{w}$ and $D \mathrm{n}$ in denitrification. In contrast, interlake studies undertaken in Norway (Kelly et al. 1987, McCrackin \& Elser 2010) and the USA (Kelly et al. 1987, McCrackin \& Elser 2012) indicate that in general, nitrate concentration in the water above the sediment correlates with the sediment denitrification rate and could thus be used as an easily measurable predictor of lacustrine $\mathrm{N}_{2}$ production at the interlake scale. These studies, however, were conducted using either the acetylene inhibition technique (McCrackin \& Elser 2012) or ${ }^{15} \mathrm{~N}$-labelling (Kelly et al. 1987), which do not account for Dn (e.g. Groffman et al. 2006). In addition, except for Kelly et al. (1987), such studies have not been performed on large geographical scales, probably because data on denitrification in boreal, lake-rich areas have been scarce (Ahlgren et al. 1994, Rissanen et al. 2011, Holmroos et al. 2012). Therefore, additional interlake studies, utilizing a technique, such as the isotope pairing technique (IPT), that accounts for both $D$ w and $D$ n
(Nielsen 1992, Steingruber et al. 2001), should be performed on different spatial scales to gain deeper insights into factors affecting denitrification.

Besides environmental factors, differences in the process rates can also be related to variations in the structure of microbial communities (e.g. Magalhães et al. 2008, Enwall et al. 2010). However, only recently has attention been paid to denitrifier and anammox communities in lake sediments (e.g. Kim et al. 2011, Rissanen et al. 2011, Yoshinaga et al. 2011). Anammox communities have usually been studied by characterizing $16 \mathrm{~S}$ rRNA gene sequence libraries generated using specific primers targeted at the anammox-branch within the Planctomycetes (e.g. Dale et al. 2009), while the denitrifier communities have most often been studied by microbial community fingerprinting (e.g. denaturing gradient gel electrophoresis [DGGE]) (Muyzer et al. 1993) of the sequence variation of nitrite reductase genes, nirK and nirS (Wallenstein et al. 2006). The only previous lake sediment study combining denitrification rate measurements with community analyses (nirK-gene based DGGE) showed that temporal and spatial variation of denitrification rates in a boreal lake was not related to the nirK-community structure (Rissanen et al. 2011). Whether the same holds true for interlake differences requires further studies.

Here, we evaluated the interlake variations and factors affecting denitrification in lakes. The study was carried out at a local scale in boreal lakes of close proximity (within $20 \mathrm{~km}$ ) as well as at regional (boreal lakes within $500 \mathrm{~km}$ ) and continental scales (boreal and temperate lakes within $2300 \mathrm{~km}$ ). At the local scale, we collected data on denitrification rates, environmental factors and microbial communities from 3 boreal lakes and complemented this data set with previously published data from Lake Ormajärvi (Rissanen et al. 2011). For the broader geographical scales, we supplemented our data set with denitrification data from 10 previously studied European lakes. We tested whether nitrate concentration in the water above the sediment is the most important factor affecting and predicting denitrification across different geographical scales, as suggested by previous studies (e.g. McCrackin \& Elser 2010, 2012). Additionally, we tested whether other environmental factors, i.e. temperature, oxygen concentration and organic matter content of sediment as well as the structure of microbial communities, affect denitrification. Finally, we assessed the variability, efficiency and controlling factors of denitrification and $\mathrm{N}$ removal capacities of lakes at different geographical scales. 


\section{MATERIALS AND METHODS}

\section{Study lakes}

Lakes Pääjärvi, Ormajärvi, Suolijärvi and Lehee, located in southern Finland, represent typical small to medium-sized boreal lakes with differences in morphometry and trophic status (Fig. 1, Table 1). Pääjärvi and the chain of Ormajärvi, Suolijärvi and Lehee form 2 separate headwater lake systems of the Kokemäenjoki River Basin draining to the Bothnian Sea in the northern part of the Baltic Sea (Fig. 1). Pääjärvi is deep, with a maximum depth of $87 \mathrm{~m}$, whereas Suolijärvi and especially Lehee are shallow. The mean residence time in Pääjärvi and Ormajärvi is $\sim 3 \mathrm{yr}$, but Suolijärvi and Lehee are flushed very quickly (mean residence time $<0.5 \mathrm{yr}$ ) (Table 1). Pääjärvi is mesotrophic, whereas the lake chain is classified as eutrophic.

Table 1. Characteristics of the study lakes at the local scale analysis

\begin{tabular}{|lcccc|}
\hline & Pääjärvi & Ormajärvi & Suolijärvi & Lehee \\
\hline Latitude $\left({ }^{\circ} \mathrm{N}\right)$ & 61.07 & 61.10 & 61.13 & 61.17 \\
Longitude $\left({ }^{\circ} \mathrm{E}\right)$ & 25.13 & 24.97 & 24.81 & 24.79 \\
Area $\left(\mathrm{km}^{2}\right)$ & 13.4 & 6.5 & 2.1 & 1.1 \\
Catchment area $\left(\mathrm{km}^{2}\right)$ & 199 & 116 & 214 & 243 \\
Max. depth $(\mathrm{m})$ & 87 & 31 & 10 & 4 \\
Mean depth $(\mathrm{m})$ & 15 & 9 & 5 & 1 \\
Mean residence & 3.3 & 2.9 & 0.4 & 0.1 \\
time $(\mathrm{yr})$ & & & & \\
\hline
\end{tabular}

Except for the polymictic Lehee, all of the lakes are dimictic and stratify thermally in summer, but they have an oxic hypolimnion throughout the open water period. Ormajärvi has a lower TOC concentration and colour value (TOC: $9.0 \mathrm{~g} \mathrm{C} \mathrm{m}^{-3}$; colour $34 \mathrm{~g} \mathrm{Pt} \mathrm{m}^{-3}$ ) than Pääjärvi, Suolijärvi and Lehee (TOC: 11 to $12.3 \mathrm{~g}$ $\mathrm{C} \mathrm{m}^{-3}$; colour 87 to $100 \mathrm{~g} \mathrm{Pt} \mathrm{m}^{-3}$ ). All of the lakes have forested catchments; forests cover $\sim 60 \%$ of catchments around Pääjärvi and Ormajärvi and $~ 70 \%$ around Suolijärvi and Lehee. Agricultural land use is highest in the catchment area of Ormajärvi (26\%) followed by Pääjärvi and Suolijärvi (18\%), whereas the agricultural land use is lowest in the catchment area of Lehee $(13 \%)$.

\section{Sample collection}

The profundal sediments of Pääjärvi, Suolijärvi and Lehee were sampled in June and October 2007 from 3 sites of differing depths (A, B and C; Fig. 1) using plexiglass tubes (diameter $=7 \mathrm{~cm}$ ) connected to a gravity corer. For the denitrification incubations, 6 to 7 sediment cores were collected from each Site A during both months and from Site C in Pääjärvi in October. In addition, 3 cores from each Site A and from Site C in Pääjärvi in October and 1 core from the rest of the Sites B and C were collected for physico-chemical and molecular analyses. Since almost half of the incubations in Site $A_{s}$ in Pääjärvi in June gave negligible denitrification rates (see 'Results'), the sampling

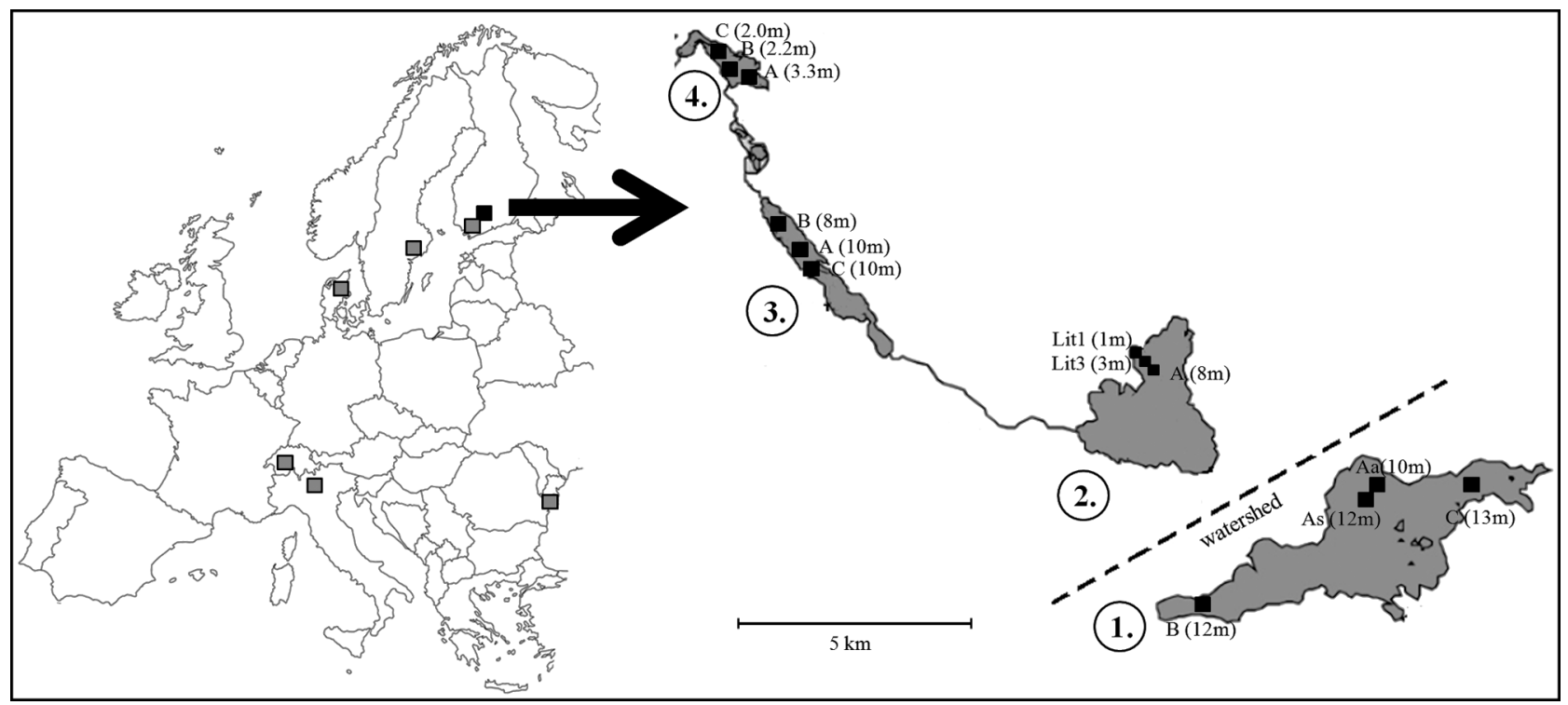

Fig. 1. Europe (left) showing the location of the boreal study lakes in the local scale analysis (black square) and the location of other lakes in the regional and continental scale analysis (grey squares) and study lakes (right) showing the location of the sampling sites (A, B and C, black squares, depths shown). Lakes are 1: Pääjärvi, 2: Ormajärvi, 3: Suolijärvi, 4: Lehee 
in October was changed to Site $\mathrm{A}_{\mathrm{a}}$, and the incubation time for this site was increased. The littoral (Sites Lit1 and Lit3) and profundal cores (Site A) from Ormajärvi (on each occasion, 3 for denitrification incubations and molecular biological analyses and 1 for physicochemical analyses and 3 additional cores for determination of ${ }^{15} \mathrm{NO}_{3}{ }^{-}$concentration in October 2006) were collected 3 times during the open-water period 2006 (June, August and October) and once in winter 2007 (February and March) (Rissanen et al. 2011) (Fig. 1). Immediately after sampling, the cores were sealed with rubber stoppers at both ends, covered with black plastic, placed in a cool box in an upright position and carefully transported to the laboratory for processing within 1 to $2 \mathrm{~h}$ of sampling.

\section{Background data analyses}

Concurrent with the sediment coring, profiles of oxygen concentrations, oxygen saturation and temperature were taken for the whole water column using a portable field meter (YSI model 58, Yellow Springs Instruments) starting $\sim 10 \mathrm{~cm}$ above the sediment surface. Concentrations of dissolved inorganic nutrients $\left(\left[\mathrm{NO}_{3}{ }^{-}+\mathrm{NO}_{2}{ }^{-}\right],\left[\mathrm{NH}_{4}{ }^{+}\right]\right.$and $\left.\left[\mathrm{PO}_{4}{ }^{3-}\right]\right)$ were measured from samples taken 2 to $3 \mathrm{~cm}$ above the sediment surface. In Pääjärvi, Suolijärvi and Lehee, inorganic nutrients were also determined from the sediment pore-water (top-most 0 to $2 \mathrm{~cm}$ ), which was extracted by centrifugation. For analyses of water column nutrients, samples were filtered through a $0.2 \mu \mathrm{m}$ pre-rinsed filter (Millipore). Inorganic phosphorus (Murphy \& Riley 1962), ammonium (Solorzano 1969) and nitrate+ nitrite $N$ (Wood et al. 1967) were determined with flow injection analysis using standard methods (QuikChem ${ }^{\circledR 8000, ~ L a c h a t ~ I n s t r u m e n t s) . ~ I n ~ a d d i t i o n, ~}$ sediments were characterized for their content of organic matter (LOI, \%) and porosity. LOI was measured as a ratio of loss of mass after combustion at high temperature $\left(450^{\circ} \mathrm{C}, 4 \mathrm{~h}\right)$ to the dry mass (determined by drying at $60^{\circ} \mathrm{C}$ for $48 \mathrm{~h}$ ).

\section{Denitrification measurements}

Denitrification was assayed in the laboratory using the isotope pairing technique (IPT) (Nielsen 1992, Risgaard-Petersen et al. 2003). A total of 1 to 3 intact subsamples of sediment and water from each sampling core were taken with plexiglass tubes of $16 \mathrm{~cm}$ in length and $2.6 \mathrm{~cm}$ in diameter. The subsamples were enriched with $\mathrm{K}^{15} \mathrm{NO}_{3}$ (98 atom \%; Cambridge Isotope Laboratories) to concentrations of 40, 80, 120 and $160 \mu \mathrm{mol} \mathrm{l}^{-1}$ ( $\mathrm{n}=2$ to 4 in each concentration). After incubations ( 3 to $4 \mathrm{~h}$, except $6 \mathrm{~h}$ for Site $\mathrm{A}_{\mathrm{a}}$, in darkness at in situ temperature), microbial activity was terminated by adding $1 \mathrm{ml} \mathrm{ZnCl}_{2}\left(1 \mathrm{~g} \mathrm{ml}^{-1}\right)$, the samples were mixed, and subsamples of the sediment-water slurry were transferred to gas-tight glass vials (12 ml; Exetainer ${ }^{\circledR}$, Labco). The samples were analysed for their mass ratios of $\mathrm{N}_{2}$ using a mass spectrometer (Europa Scientific, Roboprep-G-Plus and Tracermass) at the National Environmental Research Institute in Silkeborg, Denmark.

$D 15$ (the denitrification rate of added ${ }^{15} \mathrm{NO}_{3}{ }^{-}$) was calculated as the sum of all ${ }^{15} \mathrm{~N}$ species formed (Nielsen 1992):

$$
D 15=\left({ }^{14} \mathrm{~N}^{15} \mathrm{~N}\right)+2\left({ }^{15} \mathrm{~N}^{15} \mathrm{~N}\right)
$$

$D 14$ (the denitrification rate of natural ${ }^{14} \mathrm{NO}_{3}{ }^{-}$, henceforth referred to as denitrification) is then derived from the following equation (Nielsen 1992):

$$
D 14=D 15 \times\left({ }^{14} \mathrm{~N}^{15} \mathrm{~N}\right) /\left[2\left({ }^{15} \mathrm{~N}^{15} \mathrm{~N}\right)\right]
$$

Denitrification is then converted to units of $\mu \mathrm{mol} \mathrm{N}$ $\mathrm{m}^{-2} \mathrm{~d}^{-1}$ by multiplying by the total volume of the sample (= volume of the water phase + volume of sediment $x$ porosity) and by dividing by the surface area of the sample and the incubation time.

Dw (denitrification based on natural ${ }^{14} \mathrm{NO}_{3}^{-}$diffused to the denitrification zone from the water overlying the sediment) was calculated using the ratio of ${ }^{14} \mathrm{NO}_{3}{ }^{-}$and ${ }^{15} \mathrm{NO}_{3}{ }^{-}$available in the water phase:

$$
D \mathrm{w}=D 15 \times(a / b)
$$

where $a$ is the natural concentration of ${ }^{14} \mathrm{NO}_{3}{ }^{-}$close to the sediment surface (here assumed to be approximately the same as combined $\left.\left[\mathrm{NO}_{2}{ }^{-}+\mathrm{NO}_{3}{ }^{-}\right]\right)$, and $b$ is the added concentration of ${ }^{15} \mathrm{NO}_{3}{ }^{-}$. Thereafter, $D \mathrm{n}$ (coupled nitrification-denitrification, i.e. denitrification of ${ }^{14} \mathrm{NO}_{3}{ }^{-}$produced in the oxic sediment surface zone via nitrification) can be calculated as follows:

$$
D \mathrm{n}=D 14-D \mathrm{w}
$$

The different concentrations of ${ }^{15} \mathrm{NO}_{3}{ }^{-}$were used both to test the underlying assumptions of IPT on independence of denitrification and positive dependence of $D 15$ on added $\left[{ }^{15} \mathrm{NO}_{3}{ }^{-}\right]$(Nielsen 1992) and to detect the possible anammox activity. Presence of anammox compromises the assumption that denitrification does not depend on the added $\left[{ }^{15} \mathrm{NO}_{3}{ }^{-}\right]$ because more ${ }^{14} \mathrm{~N}^{15} \mathrm{~N}$ is produced (via pairing of ${ }^{15} \mathrm{NO}_{3}{ }^{-}$and ${ }^{14} \mathrm{NH}_{4}{ }^{+}$) than would be the case due to denitrification only (Risgaard-Petersen et al. 2003). 


\section{Molecular characterization of sediment samples}

The microbial communities in the surface layer $(0$ to $2 \mathrm{~cm}$ ) of the sediment were studied from the cores collected from Sites A, B and C in June and October 2007 and compared with the profundal samples (Site $\mathrm{A}, 0$ to $1 \mathrm{~cm}$ ) of Ormajärvi taken in June and October 2006 (Rissanen et al. 2011). In addition, a sample from the 0 to $5 \mathrm{~cm}$ surface layer of an additional core in Ormajärvi was taken on both occasions. Sediments were slurried, divided into $200 \mu \mathrm{l}$ aliquots and stored at $-20^{\circ} \mathrm{C}$ before nucleic acid extraction within 1 to 5 mo. Nucleic acids were extracted using a modified version of the bead-beating and phenol-chloroform extraction protocol of Griffiths et al. (2000) (see Rissanen et al. 2010 for further details).

16S rRNA gene PCR for anammox community studies was conducted using anammox-specific primers and a nested PCR protocol, which is highly specific for sequences related to known anammox genera (Dale et al. 2009). The primer pairs used in the analyses were Pla46F (5'-GGA TTA GGC ATG CAA GTC-3') (Neef et al. 1998)/1037R (5'-CGA CAA GGA ATT TCG CTA C-3') (Ludwig et al. 1992) and Amx368 (5'-TTC GCA ATG CCC GAA AGG-3') (Schmid et al. 2003, Amano et al. 2007)/Amx820 (5'-AAA ACC CCT CTA CTT AGT GCC C-3') (Schmid et al. 2000, Amano et al. 2007) for the first and second-round PCR, respectively. The PCR was conducted in mixtures consisting of $1 \times$ DreamTaq Buffer (Fermentas), $0.3 \mu \mathrm{mol} \mathrm{l}^{-1}$ forward/ reverse primer, $0.2 \mathrm{mmol} \mathrm{l}^{-1}$ dNTPs, $1 \mathrm{mg} \mathrm{ml}^{-1} \mathrm{BSA}$ (bovine serum albumin) and $0.4 \mathrm{U}$ DreamTaq (Fermentas). PCR products of the samples from Sites $A_{a}$ and C in Pääjärvi in October and Site A in Ormajärvi in October were subjected to cloning and sequencing to verify the specificity of the primers. 16S rRNA gene amplicons were cloned using EZ-cells (Qiagen) and a TOPO TA Cloning Kit for Sequencing (Invitrogen) according to the manufacturer's instructions. Clones were sequenced using T7 plasmid primer, a Big Dye 3.1 kit and an ABI3700 capillary sequencer (Applied Biosystems). Sequences were edited using Sequence Scanner 1.0 (Applied Biosystems). Sequence alignment, chimera-checking (Chimera-Slayer) (Haas et al. 2011) and classification to operational taxonomic units (OTUs) using $97 \%$ identity threshold were conducted in Mothur (Schloss et al. 2009). No chimeric sequences were detected. A representative sequence of each OTU was searched against databases using BLASTN (Altschul et al. 1997). 16S rRNA gene sequences were deposited in the EMBL database (European Bioinformatics Institute, www.ebi.ac.uk/embl/) under accession numbers HE583312 to 583387.
Studies of interlake and seasonal variations in denitrifier communities were carried out using nirK PCR and DGGE analysis from DNA extractions as in Rissanen et al. (2011) with the following modifications. PCR reactions of each sample were made in duplicate and pooled for DGGE analysis. A DGGE standard was made by pooling PCR products of different samples and was run between every 5 to 6 samples. The DGGE gel was stained using Sybr ${ }^{\circledR}$ Green I (Invitrogen), illuminated in blue light (Safe Imager ${ }^{\mathrm{TM}}$, Invitrogen) and photographed. DNA density curves for each lane were created after a rolling disc background subtraction, and bands (peaks) were recognized semiautomatically using Quantity One software (BioRad). Selected bands in standard lanes were aligned. Each standard band was given a pseudo-size number, i.e. the average relative front (fr) value multiplied by 1000. Pseudo-sizes were then calculated for each band in samples using Quantity-One (BioRad). Sample bands were aligned and divided into OTUs using a clustering-based peak alignment algorithm (Ishii et al. 2009) in $\mathrm{R}$ with a cut-off value representing $1 \%$ tolerance for migration shifts. The relative abundance $(\%)$ of each OTU in each lane was quantified from DNA density curves as a ratio of the total peak area to the sum of all peak areas in a lane.

\section{Statistical analyses}

The assumptions underlying the IPT regarding the first-order kinetics of $D 15$ and independence of denitrification on the added concentration of ${ }^{15} \mathrm{NO}_{3}{ }^{-}$ were tested using ANOVA (Pääjärvi, Suolijärvi and Lehee) and $t$-tests (Ormajärvi). A $t$-test was used in Ormajärvi because there were only 2 replicates for one of the ${ }^{15} \mathrm{NO}_{3}{ }^{-}$- concentration measurements. Subsamples, i.e. incubation cores, were used as replicates in these analyses. In addition, temporal variation of denitrification was tested for each lake separately using either $t$-tests or 1-way ANOVA, and interlake variations were tested using 1-way ANOVA. As a post-hoc test in ANOVA, we used the LSD technique (least significant difference) with Hochberg-Bonferroni corrections (Hochberg 1988). The averages of subsamples taken from each sampling core were used as replicates in these analyses (i.e. $\mathrm{n}=3$ to 7 for each site/season combination). For normality and homoscedasticity of variances, the denitrification and $D 15$ values were $\log _{10}$-transformed in the above-mentioned analyses.

Relationships between the environmental factors and denitrification parameters (denitrification, $D \mathrm{w}$, 
$D \mathrm{n}, D \mathrm{w} \%$ and $D \mathrm{n} \%$ ) were studied using the data of the present study supplemented with the profundal and littoral data from Ormajärvi (Rissanen et al. 2011). Site/season-specific average values of sampling cores were used in these analyses. Relationships between nitrate concentration and denitrification parameters were studied using Spearman correlation analysis and simple regression analyses. The correlations among other environmental factors and denitrification parameters were also studied using Spearman correlation. Multiple regression analyses were run for predictive relationships on denitrification, $D$ w and $D$ n. Three separate models were fitted; selected variables (temperature, $\mathrm{O}_{2}$ concentration and LOI) were fitted in pairs with nitrate (i.e. $\mathrm{NO}_{3}{ }^{-}$and $T_{i} \mathrm{NO}_{3}{ }^{-}$and $\mathrm{O}_{2} ; \mathrm{NO}_{3}{ }^{-}$and LOI). When necessary, the variables were ln-transformed for the linearity, normality and homoscedasticity of the variances. Multicollinearity was evaluated using tolerance values (always $>0.5$ ). All statistical analyses were conducted using PASW 18.0 (PASW Statistics 18, Release Version 18.0.0, SPSS, 2009).

Multivariate analyses of the nirK-DGGE data were based on Bray-Curtis dissimilarities calculated among samples using square-root transformed data of relative abundances of OTUs. The interlake and seasonal variations in the structure of the profundal nirK-carrying communities were analysed using permutational multivariate analysis of variance (PERMANOVA) (9999 permutations) (Anderson 2001, McArdle \& Anderson 2001) by applying a factorial design with season and lake as fixed factors ( 3 sites per lake, $n=3$ ). Ormajärvi was excluded from these tests because only 1 profundal site had been analysed. The nirKcommunity data were further assessed graphically using non-metric multidimensional scaling (NMS). The NMS was constrained to 2 ordination axes. To minimize the Kruskal's stress and to avoid local minimum solutions, NMS was performed with 100 runs with the real data, a random starting configuration in each run and an instability criterion of 0.0001 . Monte Carlo tests of the real data versus randomized data (200 runs with randomized data) were used to assess the significance of the solution. A final solution with minimum stress $(16.2 \%)$ was achieved with 43 iterations. The relationship between environmental factors and nirKcommunity structure and the effect of community structure on the denitrification parameters was studied using Mantel's test. Variables correlating significantly with the nirK community in Mantel's test were additionally correlated (Pearson) separately with both of the NMS axes, and the $\mathrm{R}^{2}$ values of these correlations were displayed as vectors radiating from the centre of the plot (McCune \& Grace 2002). NMS and Mantel's test were performed using PC-ORD version 4.01 (B. McCune and M. J. Mefford, PC-ORD for Windows: multivariate analysis of ecological data, 4.01 edn, MjM Software, 1999), and PERMANOVA was conducted using the program freely available from the following website: www.stat.auckland.ac.nz/ $\sim$ mja/Programs.htm.

\section{Regional (boreal zone) and continental (boreal and temperate zones) scale analyses}

Data on denitrification rates, nitrate and oxygen concentrations and temperature in the water overlying the sediment, as well as the average area-specific $\mathrm{N}$ load rates, were obtained for 10 previously studied small to medium-sized lakes, located in the boreal and temperate zone in Europe (Ahlgren et al. 1994, Mengis et al. 1997, Risgaard-Petersen et al. 1999, Friedrich et al. 2003, Nizzoli et al. 2010, Holmroos et al. 2012) (Fig. 1, see Table S1 in the supplement at www.int-res.com/articles/suppl/a069p001_supp.pdf). In these studies, denitrification was always measured with IPT in laboratory incubations of undisturbed sediment cores. Information on nitrate and oxygen concentrations and temperature in Ahlgren et al. (1994), Friedrich et al. (2003) and Nizzoli et al. (2010) were kindly provided by I. Ahlgren, J. Friedrich and D. Nizzoli, respectively. The obtained data were combined with the data from our own studies. Lakespecific average values of each parameter were used in subsequent analyses because of large interlake differences in the number of observations. The correlation and simple regression analyses were conducted as explained in the section 'Statistical analyses'. In addition, 3 multiple regression models were run for the continental data set to get a predictive relationship for denitrification as explained in the section 'Statistical analyses'. Three models where temperature, $\mathrm{O}_{2}$ concentration and latitude were fitted in pairs with nitrate concentration were created. Multiple regression analysis was not attempted with the regional data set nor with $D$ w and $D$ n of the continental data set due to low number of observations.

\section{RESULTS}

\section{Environmental factors in the study lakes}

In Lehee and Suolijärvi, sediments had very similar LOI and porosity, which were generally higher than in 
Table 2. Characteristics of sediment and the water overlying the sediment in the profundal zone of the local study lakes. Except for porewater, data are means $( \pm 1 \mathrm{SD}$ ) of samples collected from 3 profundal sites (Sites A, B and C, see Fig. 1) in Pääjärvi, Suolijärvi and Lehee and values of samples collected from 1 profundal site (Site A, see Fig. 1) in Ormajärvi. Porewater data from Pääjärvi, Suolijärvi and Lehee are from 1 site (Site A) except for Pääjärvi in October, where samples were from 2 sites (Sites A and C). $\left[\mathrm{NO}_{3}{ }^{-}\right],\left[\mathrm{NH}_{4}{ }^{+}\right],\left[\mathrm{PO}_{4}{ }^{3-}\right],\left[\mathrm{O}_{2}\right], \mathrm{O}_{2}$ sat., and $\mathrm{T}$ : concentrations of nitrate, ammonium, phosphate and oxygen, oxygen saturation and temperature of the water overlying the sediment; LOI: sediment organic matter content $(\% \text { of dry } \mathrm{mass})_{i} \mathrm{~s}\left[\mathrm{NO}_{3}{ }^{-}\right], \mathrm{s}\left[\mathrm{NH}_{4}{ }^{+}\right]$, $\mathrm{s}\left[\mathrm{PO}_{4}{ }^{3-}\right]$ : concentrations of nitrate, ammonium and phosphate in sediment porewater ( 0 to $2 \mathrm{~cm}$ surface layer)

\begin{tabular}{|c|c|c|c|c|c|c|c|c|c|c|}
\hline & \multicolumn{2}{|c|}{ —Pääjärvi —— } & \multicolumn{4}{|c|}{ - Ormajärvi — } & \multicolumn{2}{|c|}{ — Suolijärvi } & \multicolumn{2}{|c|}{ Lehee } \\
\hline & Jun & Oct & Jun & Aug & Oct & Feb & Jun & Oct & Jun & Oct \\
\hline & 2007 & 2007 & 2006 & 2006 & 2006 & 2007 & 2007 & 2007 & 2007 & \\
\hline LOI (\%) & $10.8 \pm 3.1$ & $10.4 \pm 3.7$ & 11.8 & 11.6 & 9.8 & 11.5 & $15.7 \pm 0.6$ & $15.9 \pm 0.4$ & $18.0 \pm 0.6$ & $18.0 \pm 0.5$ \\
\hline Porosity & $0.94 \pm 0.01$ & $0.94 \pm 0.02$ & 0.94 & 0.94 & 0.92 & 0.94 & $0.96 \pm 0.00$ & $0.96 \pm 0.00$ & $0.96 \pm 0.01$ & $0.96 \pm 0.00$ \\
\hline $\left.\mathrm{s}\left[\mathrm{NO}_{3}^{-}\right](\mu \mathrm{mol} \mathrm{l}]^{-1}\right)$ & 12.4 & $13.9 \pm 9.3$ & & & & & 5.1 & 8.0 & 3.1 & 4.5 \\
\hline $\mathrm{s}\left[\mathrm{NH}_{4}^{+}\right]\left(\mu \mathrm{mol} \mathrm{l}^{-1}\right)$ & 7.7 & $11.1 \pm 5.0$ & & & & & 67.1 & 92.9 & 28.4 & 60.7 \\
\hline $\mathrm{s}\left[\mathrm{PO}_{4}^{-}\right]\left(\mu \mathrm{mol} \mathrm{l} l^{-1}\right)$ & 0.61 & $0.24 \pm 0.11$ & & & & & 0.03 & 0.06 & 0.03 & 0.06 \\
\hline$T\left({ }^{\circ} \mathrm{C}\right)$ & $9.5 \pm 1.2$ & $11.3 \pm 0.6$ & 11.2 & 10.9 & 12.2 & 1.5 & $11.3 \pm 0.3$ & $9.8 \pm 0.3$ & $17.4 \pm 0.2$ & $11.8 \pm 0$ \\
\hline$\left[\mathrm{O}_{2}\right]\left(\mu \mathrm{mol} \mathrm{l} \mathrm{l}^{-1}\right)$ & $346.8 \pm 6.4$ & $322.9 \pm 15.4$ & 281.3 & 193.8 & 320.9 & 378.1 & $62.6 \pm 21.7$ & $305.2 \pm 7.2$ & $260.4 \pm 3.6$ & $315.6 \pm 8.3$ \\
\hline $\mathrm{O}_{2}$ sat. $(\%)$ & $97.4 \pm 1.2$ & $94.5 \pm 5.5$ & 82.3 & 56.2 & 95.4 & 86.1 & $18.7 \pm 6.8$ & $87.1 \pm 1.7$ & $87.7 \pm 1.6$ & $93.8 \pm 2.4$ \\
\hline$\left[\mathrm{NO}_{3}^{-}\right]\left(\mu \mathrm{mol} \mathrm{l} \mathrm{l}^{-1}\right)$ & $74.6 \pm 1.2$ & $65.0 \pm 1.3$ & 28.1 & 35.1 & 7.5 & 36.1 & $17.4 \pm 0.7$ & $12.5 \pm 1.1$ & $2.2 \pm 0.5$ & $3.5 \pm 0.8$ \\
\hline$\left[\mathrm{NH}_{4}{ }^{+}\right]\left(\mu \mathrm{mol} \mathrm{l} \mathrm{l}^{-1}\right)$ & $2.9 \pm 1.9$ & $2.7 \pm 1.0$ & 2.8 & 7.6 & 2.9 & 0.9 & $16.2 \pm 2.0$ & $7.5 \pm 5.3$ & $0.7 \pm 0.0$ & $3.3 \pm 1.9$ \\
\hline$\left[\mathrm{PO}_{4}^{-}\right]\left(\mu \mathrm{mol} \mathrm{l} l^{-1}\right)$ & $0.18 \pm 0.04$ & $0.25 \pm 0.07$ & 0.13 & 0.03 & 0.06 & 0.29 & $0.11 \pm 0.04$ & $0.14 \pm 0.02$ & $0.06 \pm 0.01$ & $0.09 \pm 0.02$ \\
\hline
\end{tabular}

Pääjärvi and Ormajärvi (Table 2). Porewater nitrate and phosphate concentrations were higher in Pääjärvi than in Suolijärvi and Lehee, whereas the opposite was true for ammonium concentrations (Table 2).

Temperature of the water overlying the sediment varied between 9.5 and $17.4^{\circ} \mathrm{C}$ during the open water period. In Pääjärvi and Lehee, the oxygen saturation in the overlying water was $>80 \%$ in June as well as in October, whereas the conditions were poorer in Suolijärvi in June $(\sim 19 \%)$ and in Ormajärvi in August (56\%). However, the hypolimnetic oxygen was replenished in both lakes during autumn overturn (Table 2). Nitrate concentration was highest in Pääjärvi followed by Ormajärvi and Suolijärvi, whereas very low concentrations were observed in Lehee. Ammonium concentration was highest in Suolijärvi. Concentration of phosphate was highest in Pääjärvi, while it was lowest in Lehee (Table 2).

\section{Denitrification rates}

The underlying assumptions of IPT on independence of denitrification and positive dependence of $D 15$ on added $\left[{ }^{15} \mathrm{NO}_{3}{ }^{-}\right]$(Nielsen 1992) could not be reliably evaluated for Site $A_{s}$ in Pääjärvi in June (see Fig. S1 in the Supplement) since almost half of the subsamples from that site showed negligible $D 15$ and denitrification (D14). This might have been due to too-short incubation times, and consequently, this site was excluded from further analyses. For the rest of the measurements, the assumptions held: denitrification appeared independent and $D 15$ positively dependent on the added ${ }^{15} \mathrm{NO}_{3}{ }^{-}$, although on 2 occasions, the latter could not be confirmed statistically (Fig. S1 in the Supple-

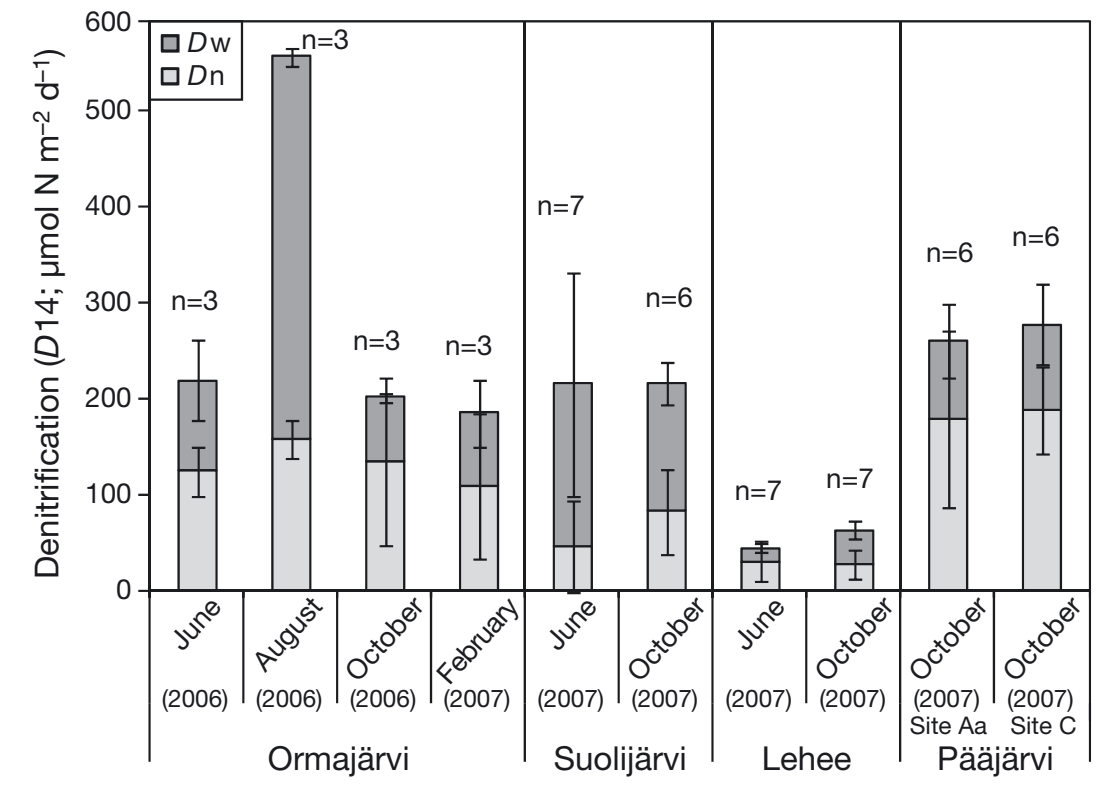

Fig. 2. Spatial and seasonal variations (mean $\pm \mathrm{SD}$ ) in the denitrification parameters in profundal sediments of the boreal study lakes. Denitrification is partitioned into $D w$ (denitrification of the nitrate from the water overlying the sediment) and $D n$ (coupled nitrification-denitrification) 
ment). Independence of denitrification on added $\left[{ }^{15} \mathrm{NO}_{3}{ }^{-}\right]$also indicates that there was no anammox activity in the studied sediments.

Mean rates of denitrification, $D \mathrm{w}$ and $D \mathrm{n}$ varied from 45 to 561 , from 14 to 404 and from 27 to 188 umol $\mathrm{N} \mathrm{m}^{-2} \mathrm{~d}^{-1}$, respectively (Fig. 2). There were interlake differences in denitrification in June and in October (June: $F=10.2, \mathrm{p}<0.01$; October: $F=23.5$, $\mathrm{p}<0.001$ ), with denitrification being lowest in Lehee (LSD: $p<0.01$ ). Denitrification was the same in Ormajärvi, Suolijärvi and Pääjärvi, and no differences were found between Sites $A_{a}$ and C in Pääjärvi (LSD: $p>0.05$ ). Denitrification did not vary between June and October in Suolijärvi $(t=-0.72, \mathrm{p}>0.05)$ nor in Lehee $(t=-1.81, \mathrm{p}>0.05)$. In Ormajärvi, denitrification peaked in August, but was otherwise stable $(F=10.9, \mathrm{p}<0.01 ; \mathrm{LSD}, \mathrm{p}<0.05)$ (Fig. 2). Differences in $D$ n and $D$ w among lakes and seasons were also detected. $D$ n dominated the denitrification in Ormajärvi and Pääjärvi except for August in Ormajärvi and was also higher in these lakes than in Lehee and Suolijärvi (Fig. 2). In contrast, $D \mathrm{w}$ dominated in Suolijärvi. The seasonal change from summer stratification to autumn overturn led to a decrease in $D \mathrm{w}$ in Ormajärvi and Suolijärvi in October but also to an increase in Dn in Suolijärvi.

Denitrification and its components, $D \mathrm{n}$ and $D \mathrm{w}$, were positively correlated with nitrate concentration in the water overlying the sediment (Table 3, Fig. 3). A nonlinear relationship between denitrification and $D$ w and nitrate concentration suggests that denitrification efficiency decreased as nitrate concentration increased (Fig. 3A,B). In addition, denitrification and nitrate concentration in the water overlying the sedi-

Table 3. Significant correlations (Spearman's rho) $(\mathrm{p}<0.05)$ between denitrification parameters and environmental factors in the 4 boreal study lakes at the local scale. Den: denitrification; $D$ n: coupled nitrification-denitrification; $D$ w: denitrification of nitrate from the water overlying the sediment; $D \mathrm{n} \%$ : share of $D \mathrm{n}$ in Den; $D \mathrm{w} \%$ : share of $D \mathrm{w}$ in Den. See Table 2 for other definitions. $\mathrm{n}=18$ in correlations between denitrification parameters and environmental factors except for porewater concentrations, where $n=6 . n=31$ in correlations among environmental factors except for porewater concentrations, where $n=7$

\begin{tabular}{|c|c|c|c|c|c|c|c|c|c|c|c|c|}
\hline & Den & $D \mathrm{n}$ & $D \mathrm{w}$ & $D n \%$ & $D \mathrm{w} \%$ & LOI & Porosity & $T$ & {$\left[\mathrm{O}_{2}\right]$} & $\mathrm{O}_{2}$ sat. & {$\left[\mathrm{NO}_{3}{ }^{-}\right]$} & {$\left[\mathrm{PO}_{4}{ }^{3-}\right]$} \\
\hline$D \mathrm{n}$ & 0.77 & & & & & & & & & & & \\
\hline$D w$ & 0.73 & & & & & & & & & & & \\
\hline$D n \%$ & & 0.59 & -0.53 & & & & & & & & & \\
\hline$D \mathrm{w} \%$ & & -0.59 & 0.53 & -1.0 & & & & & & & & \\
\hline \multicolumn{13}{|l|}{ LOI } \\
\hline Porosity & & & & & & 0.83 & & & & & & \\
\hline$T$ & -0.66 & & -0.53 & & & & & & & & & \\
\hline$\left[\mathrm{O}_{2}\right]$ & & & & & & -0.51 & -0.49 & -0.45 & & & & \\
\hline $\mathrm{O}_{2}$ sat. & & & & & & -0.58 & -0.54 & & 0.70 & & & \\
\hline$\left[\mathrm{NO}_{3}^{-}\right]$ & 0.77 & 0.70 & 0.54 & & & -0.47 & & -0.67 & 0.50 & & & \\
\hline$\left[\mathrm{PO}_{4}{ }^{3-}\right]$ & & & & & & & & -0.59 & 0.54 & & 0.77 & \\
\hline$\left[\mathrm{NH}_{4}{ }^{+}\right]$ & & & 0.58 & -0.64 & 0.64 & & 0.42 & & -0.40 & -0.51 & & \\
\hline $\mathrm{s}\left[\mathrm{NO}_{3}{ }^{-}\right]$ & 0.83 & & & & & -0.82 & & & & & 0.86 & 0.78 \\
\hline $\mathrm{s}\left[\mathrm{PO}_{4}{ }^{3-}\right]$ & 0.85 & & & & & & -0.80 & & 0.78 & & 0.80 & \\
\hline $\mathrm{s}\left[\mathrm{NH}_{4}^{+}\right]$ & & & & -0.89 & 0.89 & & & & & -0.86 & & \\
\hline
\end{tabular}
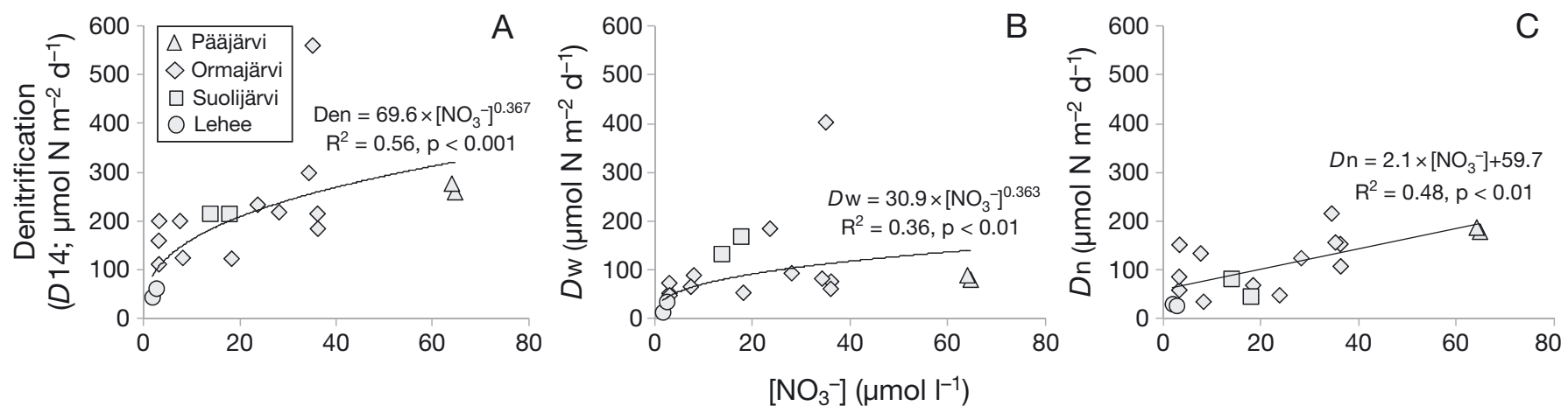

Fig. 3. Relationship between (A) denitrification, (B) Dw and (C) Dn and concentration of nitrate in the water overlying the sediment in the boreal lakes at the local study scale 
ment were correlated with the concentration of nitrate and phosphate in the sediment porewater. $D \mathrm{w}$ and $D$ w $\%$ correlated positively with ammonium concentrations in the water overlying the sediment, and $D$ w\% correlated also with porewater ammonium concentration (Table 3). Temperature and nitrate concentration were negatively correlated, and therefore, the negative dependency of denitrification and $D$ w on temperature can be explained by co-variation. Oxygen and nitrate concentrations were negatively correlated with the organic matter content of the sediment, and nitrate concentration was positively correlated with the oxygen concentration (Table 3).

The multiple regression models with oxygen concentration, temperature and LOI fitted together with nitrate concentration revealed that except for nitrate concentration in the water above the sediment, none of the variables affected denitrification or Dn. However, oxygen concentration combined with nitrate concentration explained $54 \%$ of the variation in $D \mathrm{w}$, and thus, $D \mathrm{w}$ increased when nitrate concentration increased and oxygen concentration in the water above the sediment decreased (Table 4).

\section{Molecular analyses}

Intralake variation in nirK communities was minor based on the DGGE patterns (see Fig. S2 in the Supplement) The structure of the nirK community was also temporally stable but differed among lakes (PERMANOVA: Site $\times$ Season, $F=1.37, \mathrm{p}>0.05$; Season, $F=2.02, \mathrm{p}>0.05$; Lake, $F=7.98$, $\mathrm{p}<0.001$ ). Visualization of the community structure by NMS confirmed the results of PERMANOVA analyses; temporal variations were very small, but lakes were clearly separated from each other with some overlap between the nirK communities in Lehee and Suolijärvi (Fig. 4). Sediment thickness did not affect the main result (Fig. 4).

The structure of the nirK community mostly depended on nitrate concentration in the water overlying the sediment (Mantel's test, $r=0.67, \mathrm{p}<0.001$ ) and in the sediment porewater (Mantel's test, $\mathrm{r}=$ 0.60, p < 0.01) as well as on sediment LOI (Mantel's test, $\mathrm{r}=0.55, \mathrm{p}<0.001$ ) (Table $\mathrm{S} 2$ in the Supplement, Fig. 4). There was also a weaker dependency on sediment porosity (Mantel's test, $\mathrm{r}=0.41, \mathrm{p}<0.001$ ) and phosphate concentration (Mantel's test, $\mathrm{r}=0.31, \mathrm{p}<$ 0.001 ) in the water overlying the sediment (Table S2 in the Supplement, Fig. 4). Lakes most similar in terms of sediment characteristics (Lehee and Suolijärvi) also had the most similar nirK communities.

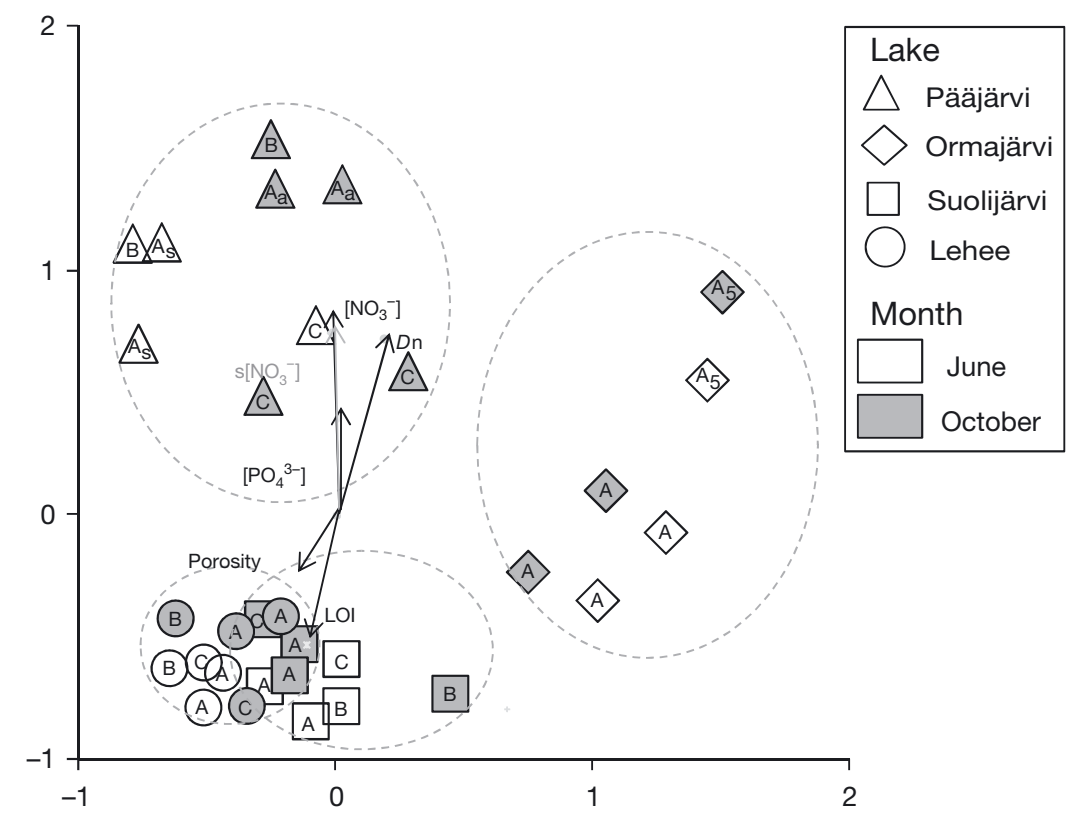

Fig. 4. Non-metric multidimensional scaling (NMS) results from the analysis of the sediment nirK community structure by DGGE. Lakes were sampled in 2007 except Ormajärvi, which was sampled in 2006. Environmental factors and process parameters correlating with nirK community structure in Mantel's test (Table S2 in the Supplement) are plotted as vectors radiating from the centre of the plot. $A\left(A_{s}, A_{a}\right), B$ and C: study sites (see Fig. 1); $A_{5}$ : sediment sample from the 0 to $5 \mathrm{~cm}$ surface layer (only in Ormajärvi)

Table 4. Multiple regression models on variation in $D w$ of the 4 local study lakes (Model 1) and in denitrification (Den) at the continental scale (Models 2 and 3). Lat.: latitude. See Table 2 for definitions and Table S1 in the Supplement for information on the data sets

\begin{tabular}{|c|c|c|c|c|c|}
\hline Model & Predictors & Equation & $\mathrm{n}$ & $\mathrm{R}^{2}$ & $\mathrm{p}$ \\
\hline 1 & {$\left[\mathrm{NO}_{3}^{-}\right],\left[\mathrm{O}_{2}\right]$} & $\ln D \mathrm{w}\left(\mu \mathrm{mol} \mathrm{N} \mathrm{m}{ }^{-2} \mathrm{~d}^{-1}\right)=0.413 \times \ln \left[\mathrm{NO}_{3}^{-}\right]\left(\mu \mathrm{mol} \mathrm{l}^{-1}\right)-0.004 \times\left[\mathrm{O}_{2}\right]\left(\mu \mathrm{mol} \mathrm{l^{-1 }}\right)+4.4$ & 18 & 0.54 & $<0.01$ \\
\hline 2 & {$\left[\mathrm{NO}_{3}^{-}\right], T$} & $\operatorname{lnDen}\left(\mathrm{nmol} \mathrm{N} \mathrm{m}{ }^{-2} \mathrm{~d}^{-1}\right)=1.042 \times \ln \left[\mathrm{NO}_{3}{ }^{-}\right]\left(\mathrm{nmol} \mathrm{l}^{-1}\right)+0.166 \times T\left({ }^{\circ} \mathrm{C}\right)+0.6$ & 13 & 0.67 & $<0.01$ \\
\hline 3 & {$\left[\mathrm{NO}_{3}^{-}\right]$, Lat. } & $\operatorname{lnDen}\left(\mathrm{nmol} \mathrm{N} \mathrm{m}{ }^{-2} \mathrm{~d}^{-1}\right)=0.580 \times \ln \left[\mathrm{NO}_{3}^{-}\right]\left(\mathrm{nmol} \mathrm{l}^{-1}\right)-0.142 \times$ Lat. $\left({ }^{\circ} \mathrm{N}\right)+14.9$ & 14 & 0.83 & $<0.001$ \\
\hline
\end{tabular}


The decrease of LOI and porosity and the increase in nitrate and phosphorus concentrations corresponded to the change in nirK communities from Lehee and Suolijärvi to Ormajärvi and Pääjärvi (Fig. 4). There was a correlation between community structure and Dn (Mantel's test, Dn: r $=0.63, \mathrm{p}<0.001$; Fig. 4) but no correlation between community structure and other denitrification parameters (Mantel's test, denitrification: $\mathrm{r}=0.17, \mathrm{p}>0.05 ; D \mathrm{w}: \mathrm{r}=-0.21, \mathrm{p}>0.05$; $D \mathrm{w} \%: \mathrm{r}=-0.07, \mathrm{p}>0.05 ; D \mathrm{n} \%: \mathrm{r}=-0.07, \mathrm{p}>0.05)$.

Using the highly anammox-specific protocol, positive PCR products could only be amplified from samples of Ormajärvi and Pääjärvi. This suggests that organisms capable of anammox were present in sediments of Ormajärvi and Pääjärvi but not in Suolijärvi and Lehee. Results of cloning and sequencing verified the high specificity of the PCR protocol: the representative sequences of OTUs showed 89 to $96 \%$ identities to 4 anammox genera, Brocadia, Jettenia, Kuenenia and Anammoxoglobus (see Table S3 in the Supplement).

\section{Comparison of denitrification between regional (boreal zone) and continental (temperate and boreal zone) scales}

At the regional (boreal) scale, denitrification and Dn were positively correlated with nitrate concentration of the water overlying the sediment (Denitrification, $\rho=0.93, \mathrm{p}<0.01 ; D \mathrm{n}, \rho=0.96, \mathrm{p}<0.001$ ) (Fig. 5A,C, Fig. S3 in the Supplement). Other significant correlations at the regional scale were not detected. In general, denitrification rates, nitrate
Table 5. Significant correlations (Spearman's rho) $(\mathrm{p}<0.05)$ between denitrification parameters and environmental factors at the continental scale. $\mathrm{N}$ load: average, area-specific $\mathrm{N}$ load. See Tables 2 \& 3 for other definitions and Table $\mathrm{S} 1$ in the Supplement for information on the data set

\begin{tabular}{|lrrrrr|}
\hline & Den & $D \mathrm{w}$ & $D \mathrm{n} \%$ & $D \mathrm{w} \%$ & N load \\
\hline$D \mathrm{w}$ & 0.90 & & & & \\
$D \mathrm{n} \%$ & -0.64 & -0.86 & & & \\
$D \mathrm{w} \%$ & 0.64 & 0.86 & -1.00 & & \\
{$\left[\mathrm{NO}_{3}{ }^{-}\right]$} & 0.75 & 0.84 & & & 1.00 \\
$T$ & & & 0.66 & -0.66 & \\
{$\left[\mathrm{O}_{2}\right]$} & & -0.67 & 0.77 & -0.77 & \\
Latitude & -0.65 & & & & \\
\hline
\end{tabular}

concentrations and $\mathrm{N}$ loads were much lower in boreal lakes $\left(>59^{\circ} \mathrm{N}\right.$ latitude) than in temperate lakes (Table S1 in the Supplement). Indeed, at the continental scale, denitrification correlated negatively with latitude (Table 5). Denitrification and $D \mathrm{w}$ correlated positively with $\mathrm{NO}_{3}{ }^{-}$concentration of the water overlying the sediment, and $\mathrm{NO}_{3}{ }^{-}$concentration correlated positively with $\mathrm{N}$ load (Table 5, Fig. 5A,B, Fig. S3 in the Supplement). In addition, $D \mathrm{w}$ and $D \mathrm{w} \%$ correlated negatively with oxygen concentration in the water above the sediment, and $D$ w\% correlated negatively with temperature (Table 5). The nonlinear relationship between denitrification and nitrate concentration suggests that denitrification efficiency decreased as nitrate concentration increased at regional as well as continental scales (Fig. 5A). There were also differences in regression curves (Fig. 5A, Fig. S3 in the Supplement). At a given nitrate concentration, denitrifica-
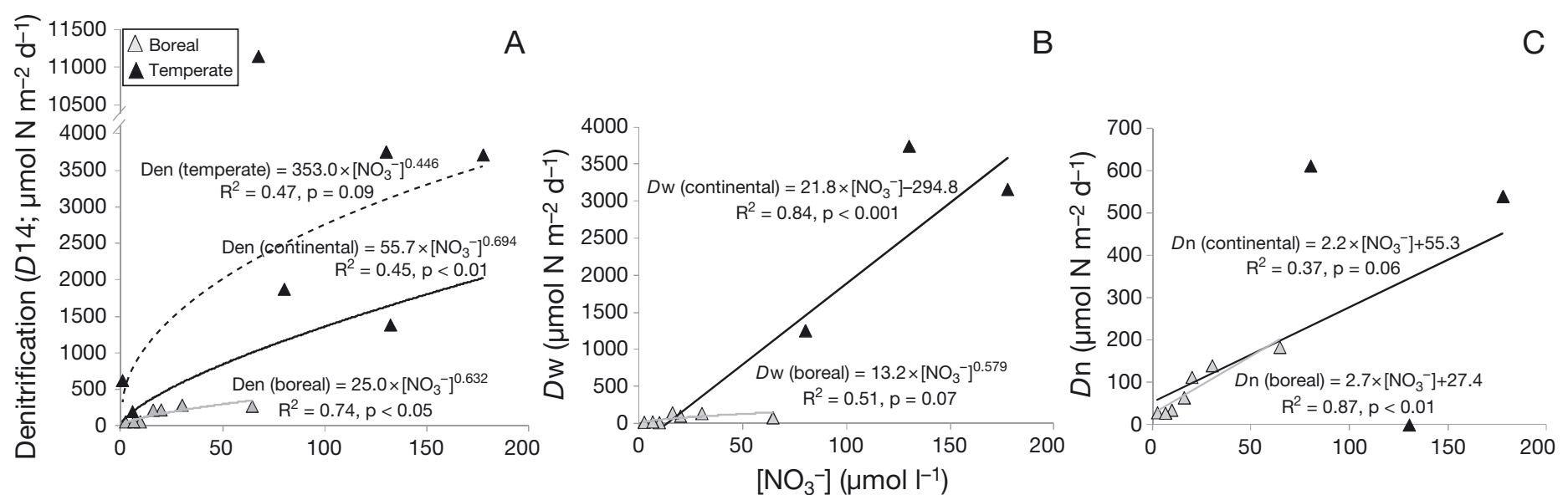

Fig. 5. Relationship between (A) denitrification, (B) Dw and (C) Dn and concentration of nitrate in the water overlying the sediment in the combined data set of the 4 boreal study lakes and 10 other European lakes (see Fig. 1 and Table S1 in the Supplement for information on the data set). Regression lines were fitted to the whole continental data set (black, solid lines) and separately to boreal (grey lines) and (A) temperate (black, dashed line) data sets 
tion rates estimated by the models were higher in the continental than in the regional scale. In addition, a regression model fitted for temperate data, although not statistically significant ( $p=0.09$ ), estimated highest denitrification rates. Thus, the areal variations in denitrification cannot be explained only by variable nitrate concentrations. The multiple regression analysis of the continental data set showing a positive effect of decreasing latitude on denitrification confirmed the finding (Table 4). The results suggest that nitrate removal by denitrification was less efficient in boreal than in temperate lakes. Another regression model also suggested that at the continental scale, temperature together with nitrate has a positive effect on denitrification (Table 4).

\section{DISCUSSION}

Our studies, together with previous studies, show that denitrification rates in lake sediments vary considerably seasonally (e.g. Ahlgren et al. 1994, Rissanen et al. 2011) as well as spatially, i.e. there are intralake (e.g. Saunders \& Kalff 2001b, Rissanen et al. 2011) and interlake variations (e.g. McCrackin \& Elser 2010). In conjunction with Kelly et al. (1987) and McCrackin \& Elser $(2010,2012)$, our study indicates that nitrate concentration in the water above the sediment is the most important factor predicting denitrification at variable geographical scales. This is in accordance with studies on wetlands (Kjellin et al. 2007), streams (Mulholland et al. 2008) and estuaries (Nielsen et al. 1995, Kana et al. 1998) as well as with a meta-analysis on various aquatic systems (oceans, coastal ecosystems, estuaries, lakes and rivers) (PiñaOchoa \& Álvarez-Cobelas 2006). Nitrate concentrations are partially explained by $\mathrm{N}$ loads (e.g. McCrackin \& Elser 2010), and thus, the results indicate that lake sediments have capacity to respond to increases in $\mathrm{N}$ loading (e.g. Seitzinger et al. 2006, McCrackin \& Elser 2010). However, the non-linear regressions suggest that denitrification efficiency (the proportion of the nitrate removed by the process) decreases as the nitrate concentration (and $\mathrm{N}$ load) increases, as has been previously shown in streams (Mulholland et al. 2008).

Increasing nitrate concentration in the water above the sediment affected denitrification through increase in $D$ w, as also shown before (e.g. Nielsen et al. 1995). In addition, decreasing oxygen concentration in the water further stimulated $D w$ at the local as well as continental scale by reducing the diffusional distance of nitrate from the water column to the de- nitrification zone (e.g. Rysgaard et al. 1994). The effect of oxygen concentration was especially clear in the seasonal variation at the local scale, when $D$ w in Ormajärvi and Suolijärvi decreased from summer to autumn coinciding with the autumn turnover and resulting replenishment of oxygen conditions. However, Dn also correlated positively with nitrate concentration. This suggests that the relationship between nitrate concentration and denitrification is not a simple causality because $D \mathrm{n}$, unlike $D \mathrm{w}$, should not depend on nitrate concentration in the water overlying the sediment. Correlation analyses at the local scale indicated that nitrate concentrations increased when oxygen concentration was high and sediment organic matter content low. In these conditions, nitrification was probably increased via extension of the oxic nitrification zone (Rysgaard et al. 1994) and by less severe microbial competition for inorganic nitrogen (Strauss \& Lamberti 2000). This led to increased $D$ n but also to increased flux of nitrate from sediment to the water above the sediment, resulting in the positive correlation between $D \mathrm{n}$ and nitrate concentration. This was seen in interlake differences, where, in comparison to Suolijärvi and Lehee, Pääjärvi and Ormajärvi had higher Dn and concentrations of nitrate in the water column (and sediment porewater) and lower concentrations of organic matter in the sediment. Denitrification and nitrate concentrations were especially low in the polymictic, shallow Lehee, where the euphotic zone covers the whole water column and competition for nutrients is presumably severe. Similarly, competition between algae and nitrifiers/denitrifiers for inorganic $\mathrm{N}$ was suggested to limit denitrification in the littoral zone of Ormajärvi (Rissanen et al. 2011). Thus, besides $\mathrm{N}$ load, interlake variation in nitrate concentration in the water overlying the sediment is caused by differences in processes producing/consuming nitrate. The concentration of nitrate reflects thus the overall availability of nitrate to denitrifiers.

According to studies on 5 Finnish lakes (Rissanen et al. 2011, Holmroos et al. 2012, present study) and those on 2 lakes in central Sweden (Ahlgren et al. 1994), the denitrification rates ( $\sim 0$ to $\sim 600 \mu \mathrm{mol} \mathrm{N} \mathrm{m}{ }^{-2}$ $\mathrm{d}^{-1}$ ) of boreal lakes are among the lowest reportedfrom lacustrine sediments (global range 0 to $15000 \mu \mathrm{mol} \mathrm{N} \mathrm{m}{ }^{-2} \mathrm{~d}^{-1}$ ) (Rissanen et al. 2011 and references therein). Positive correlation between nitrate concentration and $\mathrm{N}$ load suggests that the higher denitrification rates of temperate lakes stem at least partly from higher anthropogenic $\mathrm{N}$ loads (Seitzinger et al. 2002). The less efficient removal of nitrate by denitrification at the boreal zone, however, suggests 
that other factors besides co-varying $\mathrm{N}$ loads and nitrate concentrations contribute to the areal differences. The lower temperatures in the boreal than in the temperate zone might underlie this pattern, as indicated by multiple regression analysis at the continental scale. In addition, areal variations in the amount and/or quality of electron donors (organic matter), which were not assessed in the present study, might contribute to the observed differences (e.g. Hietanen \& Kuparinen 2008); more eutrophic temperate lakes with higher primary production provide more labile organic matter to denitrifiers than more oligotrophic boreal lakes. There can also be areal differences in other nitrate-consuming processes, such as dissimilatory nitrate reduction to ammonium (DNRA). In 2 Italian lakes (Lake Ca'Stanga and Lake Verde, DNRA: 70 to $120 \mu \mathrm{mol} \mathrm{m} \mathrm{m}^{-2}$ $\mathrm{d}^{-1}, 3$ to $9 \%$ of the denitrification rate) (Nizzoli et al. 2010) and 1 Swiss lake (Lake Baldegg, DNRA: 160 to $180 \mu \mathrm{mol} \mathrm{m} \mathrm{m}^{-2} \mathrm{~d}^{-1}, 4$ to $5 \%$ of the denitrification rate) (Mengis et al. 1997), DNRA is, however, of minor importance, but unfortunately there are no studies on boreal lakes. Finally, areal variations in the structure and abundance of denitrifier communities can also underlie the differences. Further studies are required to elucidate the role of these factors.

Studies on denitrifier community composition in relation to denitrification indicate that the activity can be affected by community composition (e.g. Magalhães et al. 2008, Enwall et al. 2010). However, our results on uncoupling of the nirK-community structure and denitrification activity both within (Rissanen et al. 2011) and among lakes suggest that denitrification is controlled by environmental factors rather than by the structure of the nirK community. In addition, the nirK community was seasonally very stable, despite clear seasonality in environmental factors, which contrasts with previous studies of nirK communities in aquatic sediments (Fortunato et al. 2009) and agricultural land (Wolsing \& Priemé 2004, Wertz et al. 2009) and with the nos $Z$ communities in sediments (Scala \& Kerkhof 2000, Magalhães et al. 2008). However, the result is consistent with the study of Desnues et al. (2007) in a hypersaline microbial mat. Different denitrifier communities may thus respond differently to changes in environmental conditions. Lehee and Suolijärvi, with low Dn, low concentrations of nitrate in the water overlying the sediment and in the sediment porewater and high contents of organic matter in the sediment, had very similar nirK communities, whereas the communities were different in Pääjärvi and Ormajärvi. Our results, thus, suggest that the structure of the nirK community is regulated by the availability of nitrate and sediment characteristics, which is consistent with earlier studies (Angeloni et al. 2006, Wallenstein et al. 2006, Kjellin et al. 2007, Magalhães et al. 2008, Wu et al. 2008). Thus, although availability of nitrate may immediately affect denitrification, it also acts more slowly through changes in community composition of denitrifiers (Wallenstein et al. 2006). The total abundance of nirK denitrifiers may also vary spatially and temporally (Dandie et al. 2008), and it has been reported to correlate with denitrification activity in stream sediments (O'Connor et al. 2006). The nirS community was not addressed in the present study, due to technical problems in the nirSDGGE, but it is possible that the response to environmental factors varies between nirK and nirS communities (Desnues et al. 2007, Junier et al. 2008, Enwall et al. 2010, Kim et al. 2011). A more complete picture of the denitrifier community could be acquired by concurrent analyses of nirS-containing communities and the total abundance of denitrification genes by qPCR.

Although we found genetic potential for anammox in sediments of 2 out of the 4 study lakes, denitrification was the primary microbial process producing $\mathrm{N}_{2}$ gas in the IPT incubation. However, anammox activity can be strictly seasonal (Hietanen 2007, Jäntti et al. 2011), possibly due to temporary release of competition between denitrifiers and anammox organisms for nitrate/nitrite (Jäntti et al. 2011). Since the ${ }^{15} \mathrm{NO}_{3}{ }^{-}$concentration series experiments in lakes with genetic potential for anammox were conducted only in autumn, it is possible that we missed the time of active anammox. It is also possible that there was anammox but the activities were below the detection limit of the r-IPT assay. The development of anammox communities requires stable environmental conditions due to slow growth of these bacteria (e.g. Hu et al. 2011), and it is thus likely that the conditions in lakes undergoing seasonal variations in physicochemical conditions are not stable enough. Lacustrine anammox activities in situ have only been detected in very stable conditions, i.e. in anoxic water columns of meromictic lakes (Schubert et al. 2006, Hamersley et al. 2009). In the future, the in situ anammox activity of lake sediments should be assessed with more sensitive techniques than ${ }^{15} \mathrm{NO}_{3}{ }^{-}$ concentration series through seasonal sampling in lakes with genetic potential for the process (Thamdrup \& Dalsgaard 2002, Trimmer et al. 2006).

The annual N removal by denitrification in Suolijärvi, Lehee and Pääjärvi was crudely estimated by multiplying the mean daily denitrification rate by the 


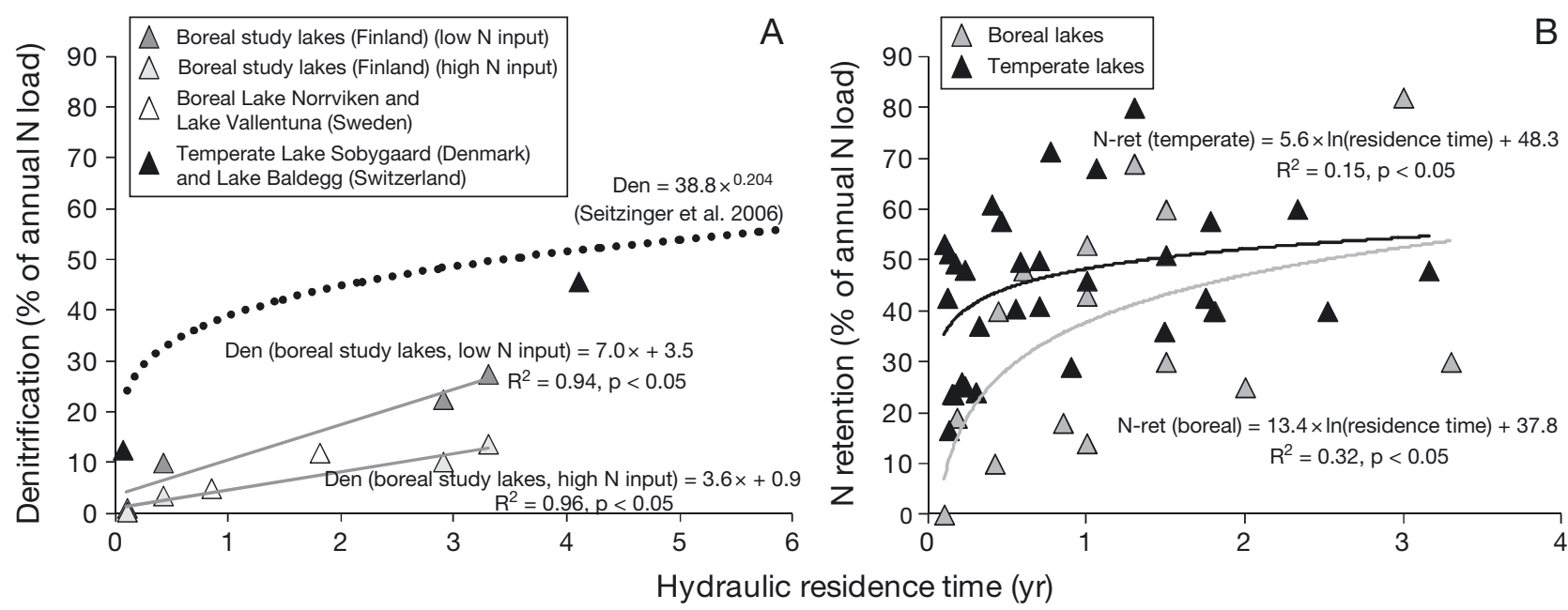

Fig. 6. (A) Proportion (\%) of the annual N load removed by denitrification (Den) in the boreal study lakes (Rissanen et al. 2011, present study) and in some other European lakes (Ahlgren et al. 1994, Mengis et al. 1997, Risgaard-Petersen et al. 1999) and (B) the proportion of the annual $\mathrm{N}$ load retained (N-ret; sedimented + denitrified) in boreal (Finland, Sweden, Estonia) and temperate lakes (see Table S4 in the Supplement for references), plotted against the average hydraulic residence time. $\mathrm{N}$ load data of the boreal study lakes (A) were for 2 years of contrasting hydrological conditions with low (year 2003) and high (year 2004) N inputs (L. Arvola et al. unpubl., S. Mäkelä et al. unpubl.). Also shown are the regression lines of the relationships for (A) the boreal study lakes (grey, solid lines) and aquatic systems in general as summarized by Seitzinger et al. (2006) (black, dotted line), and for (B) the boreal (grey, solid line) and temperate (black, solid line) lakes

lake area and 365 d. In Ormajärvi, we also took into account the spatial and temporal integration (Rissanen et al. 2011). The estimated annual removal of $\mathrm{N}$ was 17900, 7400, 2400 and $300 \mathrm{~kg}$ for Pääjärvi, Ormajärvi, Suolijärvi and Lehee, respectively. Dividing this by the annual $\mathrm{N}$ load for 2 years of contrasting hydrological conditions representing low (year 2003) and high (year 2004) N inputs to lakes (L. Arvola et al. unpubl., S. Mäkelä et al. unpubl.), gives estimates of the upper and lower limits for the annual removal of $\mathrm{N}$ by denitrification (Fig. 6A). This varied between 0.4 and $26.6 \%$ depending on the average hydraulic residence time (cf. Seitzinger et al. 2006) (Fig. 6A). With a longer residence time, there are more opportunities for sediment-water contact (Saunders \& Kalff 2001a). Indeed, $D \mathrm{n}$, which represents nitrificationdenitrification of ammonium released from organic matter during decomposition, was much higher in Pääjärvi and Ormajärvi, both with long residence times, than in Lehee and Suolijärvi. The interlake differences might also be explained by differences in the quality of $\mathrm{N}$ loads, i.e. the proportion of easily recyclable inorganic $\mathrm{N}$ to organic $\mathrm{N}$ in the $\mathrm{N}$ loads might be higher in Pääjärvi and Ormajärvi, which have lower forest coverage and higher agricultural land use in the catchment areas.

The proportion of the $\mathrm{N}$ load denitrified in our study lakes, however, is considerably lower than reported by Seitzinger et al. (2006) (Fig. 6A). Our estimates are in agreement with those from 2 boreal lakes in Sweden (Ahlgren et al. 1994), but the estimates from 2 temperate lakes in Denmark (RisgaardPetersen et al. 1999) and Switzerland (Mengis et al. 1997) are higher (Fig. 6A). These results indicate that boreal lakes are less efficient in removing their $\mathrm{N}$ loads as $\mathrm{N}_{2}$ gas than temperate lakes. Total $\mathrm{N}$ retention (denitrification $+\mathrm{N}$ sedimentation) of boreal and temperate lakes was also compared with the finding that in both areas $\mathrm{N}$ retention depends positively on hydraulic residence time (Fig. 6B, Table S4 in the Supplement). However, boreal lakes were generally less efficient in total $\mathrm{N}$ retention. These results might be due to the above-mentioned reasons underlying the areal differences in the efficiency of denitrification but might also stem from differences in the quality of $\mathrm{N}$ load, since in temperate zones, agriculture is more intensive with higher use of inorganic fertilizers (Seitzinger et al. 2002).

IPT and other measurement methods based on laboratory assays usually give lower estimates of denitrification compared to annual whole-lake estimates using indirect mass balance methods (e.g. Ahlgren et al. 1994). This has been attributed to inadequate spatial and temporal coverage (e.g. Mengis et al. 1997) or to unsuccessful simulation of in situ conditions (Risgaard-Petersen et al. 1999). On the other hand, mass balance methods may also yield inaccurate estimates due to difficulties in measuring or estimating 
all of the components of the $\mathrm{N}$ budget. In future measurements of denitrification, more attention should be paid to adequate coverage of spatial and temporal variation. Mesocosm measurements (Risgaard-Petersen et al. 1999) and methods based on in situ measurements of isotopic composition and concentration of accumulating nitrogen gas (and nitrous oxide) (Deemer et al. 2011, Tiirola et al. 2011) deserve further exploration.

\section{CONCLUSIONS}

Denitrification was the primary process producing $\mathrm{N}_{2}$ gas in lakes, but rates varied considerably among lakes at the local, regional and continental scales, mainly as a result of varying nitrate availability. Nitrate concentration in the water above the sediment was a good predictor of denitrification at the local and regional scales. At a given nitrate concentration, however, denitrification was less efficient in boreal than in temperate lakes. Future studies should focus on factors explaining the slow rates of denitrification in the boreal region despite the relatively high nitrate concentrations.

Acknowledgements. We thank the staff of Lammi Biological Station, University of Helsinki, where most of the analyses as well as denitrification incubations were performed. We thank D. Nizzoli, I. Ahlgren and J. Friedrich for providing data on nitrate and oxygen concentrations and temperature. In addition, we thank H. Devlin, R. Jones, S. Hallin and B. Thamdrup for their helpful comments on the manuscript. The comments and suggestions of the 3 anonymous reviewers and the editor are also highly appreciated. This study was funded by the Finnish Cultural Foundation, Maa- ja Vesitekniikan Tuki ry, Maj and Tor Nessling Foundation and the Academy of Finland (Projects 120089 and 123725).

\section{LITERATURE CITED}

Ahlgren I, Sörensson F, Waara T, Vrede K (1994) Nitrogen budgets in relation to microbial transformations in lakes. Ambio 23:367-377

Altschul SF, Madden TL, Schäffer AA, Zhang J, Zhang Z, Miller W, Lipman DJ (1997) Gapped BLAST and PSIBLAST: a new generation of protein database search programs. Nucleic Acids Res 25:3389-3402

Amano T, Yoshinaga I, Okada K, Yamagishi T and others (2007) Detection of anammox activity and diversity of anammox bacteria-related 16S rRNA genes in coastal marine sediment in Japan. Microbes Environ 22:232-242

Andersen JM (1974) Nitrogen and phosphorus budgets and the role of sediments in six shallow Danish lakes. Arch Hydrobiol 74:528-550

Anderson MJ (2001) A new method for non-parametric multivariate analysis of variance. Austral Ecol 26:32-46
Angeloni NL, Jankowski KJ, Tuchman NC, Kelly JJ (2006) Effects of an invasive cattail species (Typhaxglauca) on sediment nitrogen and microbial community composition in a freshwater wetland. FEMS Microbiol Lett 263: 86-92

Berounsky VM, Nixon SW (1990) Temperature and the annual cycle of nitrification in waters of Narragansett Bay. Limnol Oceanogr 35:1610-1617

Bruesewitz DA, Tank JL, Hamilton SK (2009) Seasonal effects of zebra mussels on littoral nitrogen transformation rates in Gull Lake, Michigan, U.S.A. Freshw Biol 54: $1427-1443$

Cornwell JC, Kemp WM, Kana TM (1999) Denitrification in coastal ecosystems: methods, environmental controls, and ecosystem level controls, a review. Aquat Ecol 33: 41-54

Dale OR, Tobias CR, Song B (2009) Biogeographical distribution of diverse anaerobic ammonium oxidizing (anammox) bacteria in Cape Fear River Estuary. Environ Microbiol 11:1194-1207

Dandie CE, Burton DL, Zebarth BJ, Henderson SL, Trevors JT, Goyer C (2008) Changes in bacterial denitrifier community abundance over time in an agricultural field and their relationship with denitrification activity. Appl Environ Microbiol 74:5997-6005

Deemer BR, Harrison JA, Whitling EW (2011) Microbial dinitrogen and nitrous oxide production in a small eutrophic reservoir: an in situ approach to quantifying hypolimnetic process rates. Limnol Oceanogr 56: 1189-1199

> Desnues C, Michotey VD, Wieland A, Zhizang C, Fourçans A, Duran R, Bonin PC (2007) Seasonal and diel distributions of denitrifying and bacterial communities in a hypersaline microbial mat (Camargue, France). Water Res 41:3407-3419

- Dillon PJ, Molot LA (1990) The role of ammonium and nitrate retention in the acidification of lakes and forested catchments. Biogeochemistry 11:23-43

Ekholm P, Malve O, Kirkkala T (1997) Internal and external loading as regulators of nutrient concentrations in the agriculturally loaded Lake Pyhäjärvi (southwest Finland). Hydrobiologia 345:3-14

- Enwall K, Throbäck IN, Stenberg M, Söderström M, Hallin S (2010) Soil resources influence spatial patterns of denitrifying communities at scales compatible with land management. Appl Environ Microbiol 76:2243-2250

- Fortunato CS, Carlini DB, Ewers E, Bushaw-Newton KL (2009) Nitrifier and denitrifier molecular operational taxonomic unit compositions from sites of a freshwater estuary of Chesapeake Bay. Can J Microbiol 55:333-346

Friedrich J, Dinkel C, Grieder E, Radan S, Secrieru D, Steingruber S, Wehrli B (2003) Nutrient uptake and benthic regeneration in Danube Delta Lakes. Biogeochemistry 64:373-398

> Griffiths RI, Whiteley AS, O'Donnell AG, Bailey MJ (2000) Rapid method for coextraction of DNA and RNA from natural environments for analysis of ribosomal DNA- and rRNA-based microbial community composition. Appl Environ Microbiol 66:5488-5491

- Groffman PM, Altabet MA, Böhlke JK, Butterbach-Bahl K and others (2006) Methods for measuring denitrification: diverse approaches to a difficult problem. Ecol Appl 16: 2091-2122

Haas BJ, Gevers D, Earl AM, Felgarden M and others (2011) Chimeric 16S rRNA sequence formation and detection 
in Sanger and 454-pyrosequenced PCR amplicons. Genome Res 21:494-504

- Hamersley MR, Woebken D, Boehrer B, Schultze M, Lavik G, Kuypers MM (2009) Water column anammox and denitrification in a temperate permanently stratified lake (Lake Rassnitzer, Germany). Syst Appl Microbiol 32: 571-582

> Harrison JA, Maranger RJ, Alexander RB, Giblin AE and others (2009) The regional and global significance of nitrogen removal in lakes and reservoirs. Biogeochemistry 93:143-157

> Hietanen S (2007) Anaerobic ammonium oxidation (anammox) in sediments of the Gulf of Finland. Aquat Microb Ecol 48:197-205

> Hietanen S, Kuparinen J (2008) Seasonal and short-term variation in denitrification and anammox at a coastal station on the Gulf of Finland, Baltic Sea. Hydrobiologia 596:67-77

- Hochberg Y (1988) A sharper Bonferroni procedure for multiple tests of significance. Biometrika 75:800-802

Holmroos H, Hietanen S, Niemistö J, Horppila J (2012) Sediment resuspension and denitrification affect the nitrogen to phosphorus ratio of shallow lake waters. Fundam Appl Limnol 180:193-205

> Hu BL, Shen LD, Xu CY, Zheng P (2011) Anaerobic ammonium oxidation in different natural ecosystems. Biochem Soc Trans 39:1811-1816

> Ishii S, Kadota K, Senoo K (2009) Application of a clusteringbased peak alignment algorithm to analyze various DNA fingerprinting data. J Microbiol Methods 78:344-350

> Jäntti H, Stange F, Leskinen E, Hietanen S (2011) Seasonal variation in nitrification and nitrate-reduction pathways in coastal sediments in the Gulf of Finland, Baltic Sea. Aquat Microb Ecol 63:171-181

Jeppesen E, Jensen JP, Søndergaard M, Lauridsen T, Møller PH, Sandby K (1998) Changes in nitrogen retention in shallow eutrophic lakes following a decline in density of cyprinids. Arch Hydrobiol 142:129-151

Junier P, Kim OS, Witzel KP, Imhoff JF, Hadas O (2008) Habitat partitioning of denitrifying bacterial communities carrying nirS or nirK genes in the stratified water column of Lake Kinneret, Israel. Aquat Microb Ecol 51:129-140

Kana TM, Sullivan MB, Cornwell JC, Groszkowski KM (1998) Denitrification in estuarine sediments determined by membrane inlet mass spectrometry. Limnol Oceanogr 43:334-339

Kelly CA, Rudd JWM, Hesslein RH, Schindler DW and others (1987) Prediction of biological acid neutralization in acid-sensitive lakes. Biogeochemistry 3:129-140

Kim OS, Imhoff JF, Witzell KP, Junier P (2011) Distribution of denitrifying bacterial communities in the stratified water column and sediment-water interface in two freshwater lakes and the Baltic Sea. Aquat Ecol 45:99-112

Kjellin J, Hallin S, Wörman A (2007) Spatial variations in denitrification activity in wetland sediments explained by hydrology and denitrifying community structure. Water Res 41:4710-4720

Kronvang B, Jensen JP, Hoffmann CC, Boers P (2008) Nitrogen transport and fate in European streams, rivers, lakes, and wetlands. In: Hatfield JL, Follett RF (eds) Nitrogen in the environment. Sources, problems, and management. Academic Press, Elsevier, San Diego, CA, p 241-270

Kuosa H, Arvola L, Bärlund I, Ekholm P and others (2006) Itämeren rehevöitymiseen on vaikutettava maalla ja merellä. Vesitalous 47:20-25
Leavitt PR, Brock CS, Ebel C, Patoine A (2006) Landscapescale effects of urban nitrogen on a chain of freshwater lakes in central North America. Limnol Oceanogr 51: 2262-2277

> Lepistö A, Granlund K, Kortelainen P, Räike A (2006) Nitrogen in river basins: sources, retention in the surface waters and peatlands, and fluxes to estuaries in Finland. Sci Total Environ 365:238-259

Ludwig W, Kirchof G, Klugbauer N, Weizenegger M and others (1992) Complete 23S ribosomal RNA sequences of Gram-positive bacteria with a low DNA G+C content. Syst Appl Microbiol 15:487-501

Magalhães C, Bano N, Wiebe WJ, Bordalo AA, Hollibaugh JT (2008) Dynamics of nitrous oxide reductase genes (nosZ) in intertidal rocky biofilms and sediments of the Douro River estuary (Portugal), and their relation to Nbiogeochemistry. Microb Ecol 55:259-269

> McArdle BH, Anderson MJ (2001) Fitting multivariate models to community data: a comment on distance-based redundancy analysis. Ecology 82:290-297

McCrackin ML, Elser JJ (2010) Atmospheric nitrogen deposition influences denitrification and nitrous oxide production in lakes. Ecology 91:528-539

McCrackin ML, Elser JJ (2012) Denitrification kinetics and denitrifier abundances in sediments of lakes receiving atmospheric nitrogen deposition (Colorado, USA). Biogeochemistry 108:39-54

McCune B, Grace JB (2002) Analysis of ecological communities. MjM Software Design, Gleneden Beach, OR

> Mengis M, Gachter R, Wehrli B, Bernasconi S (1997) Nitrogen elimination in two deep eutrophic lakes. Limnol Oceanogr 42:1530-1543

> Molot LA, Dillon PJ (1993) Nitrogen mass balances and denitrification rates in central Ontario lakes. Biogeochemistry 20:195-212

Mulholland PJ, Helton AM, Poole GC, Hall RO Jr and others (2008) Stream denitrification across biomes and its response to anthropogenic nitrate loading. Nature 452:202-205

Murphy J, Riley JP (1962) A modified single solution method for determination of phosphate in natural waters. Anal Chim Acta 27:31-36

> Muyzer G, Dewaal EC, Uitterlinden AG (1993) Profiling of complex microbial populations by denaturing gradient gel electrophoresis analysis of polymerase chain reaction-amplified genes coding for $16 \mathrm{~S}$ ribosomal-RNA. Appl Environ Microbiol 59:695-700

Neef A, Amann RI, Schlesner H, Schleifer KH (1998) Monitoring a widespread bacterial group: in situ detection of planctomycetes with 16S rRNA-targeted probes. Microbiology 144:3257-3266

Nielsen LP (1992) Denitrification in sediment determined from nitrogen isotope pairing. FEMS Microbiol Lett 86: 357-362

Nielsen K, Nielsen LP, Rasmussen P (1995) Estuarine nitrogen retention independently estimated by the denitrification rate and mass balance methods: a study of Norsminde Fjord, Denmark. Mar Ecol Prog Ser 119:275-283

> Nizzoli D, Carraro E, Nigro V, Viaroli P (2010) Effect of organic enrichment and thermal regime on denitrification and dissimilatory nitrate reduction to ammonium (DNRA) in hypolimnetic sediments of two lowland lakes. Water Res 44:2715-2724

> Nóges P (2005) Water and nutrient mass balance of the partly meromictic temperate Lake Verevi. Hydrobiologia $547: 21-31$ 
Nõges P, Järvet A, Tuvikene L, Nõges T (1998) The budgets of nitrogen and phosphorus in shallow eutrophic Lake Võrtsjärv (Estonia). Hydrobiologia 363:219-227

O'Connor BL, Hondzo M, Dopraca D, LaPara TM, Finlay JC, Brezonik PL (2006) Quantity-activity relationship of denitrifying bacteria and environmental scaling in streams of a forested watershed. J Geophys Res 111, G04014, doi:10.1029/2006JG000254

Oravainen R (2005) Näkökohtia typpikeskusteluun. Vesitalous 45:36-39

Pietiläinen OP (ed) (2008) Yhdyskuntien typpikuormitus ja pintavesien tila. Suomen Ympäristö 46. Finnish Environment Institute (SYKE), Helsinki (in Finnish)

Piña-Ochoa E, Álvarez-Cobelas M (2006) Denitrification in aquatic environments: a cross-system analysis. Biogeochemistry 81:111-130

Risgaard-Petersen N, Skårup S, Nielsen LP (1999) Denitrification in a soft bottom lake: evaluation of laboratory incubations. Aquat Microb Ecol 17:279-287

Risgaard-Petersen N, Nielsen LP, Rysgaard S, Dalsgaard T, Meyer RL (2003) Application of the isotope pairing technique in sediments where anammox and denitrification coexist. Limnol Oceanogr Methods 1:63-73

Rissanen AJ, Kurhela E, Aho T, Oittinen T, Tiirola M (2010) Storage of environmental samples for guaranteeing nucleic acid yields for molecular microbiological studies. Appl Microbiol Biotechnol 88:977-984

- Rissanen AJ, Tiirola M, Ojala A (2011) Spatial and temporal variation in denitrification and in the denitrifier community in a boreal lake. Aquat Microb Ecol 64:27-40

Rysgaard S, Risgaard-Petersen N, Sloth NP, Jensen $K$, Nielsen LP (1994) Oxygen regulation of nitrification and denitrification in sediments. Limnol Oceanogr 39: 1643-1652

Saunders DL, Kalff J (2001a) Nitrogen retention in wetlands, lakes and rivers. Hydrobiologia 443:205-212

Saunders DL, Kalff J (2001b) Denitrification rates in the sediments of Lake Memphremagog, Canada-USA. Water Res 35:1897-1904

Scala DJ, Kerkhof LJ (2000) Horizontal heterogeneity of denitrifying bacterial communities in marine sediments by terminal restriction fragment length polymorphism analysis. Appl Environ Microbiol 66:1980-1986

Schloss PD, Westcott SL, Ryabin T, Hall JR and others (2009) Introducing mothur: open-source, platform-independent, community-supported software for describing and comparing microbial communities. Appl Environ Microbiol 75:7537-7541

Schmid M, Twachtmann U, Klein M, Strous M and others (2000) Molecular evidence for genus level diversity of bacteria capable of catalyzing anaerobic ammonium oxidation. Syst Appl Microbiol 23:93-106

Schmid M, Walsh K, Webb RI, Rijpstra WI and others (2003) Candidatus 'Scalindua brodae', sp. nov., Candidatus 'Scalindua wagneri', sp. nov., two new species of anaerobic ammonium oxidizing bacteria. Syst Appl Microbiol 26:529-538

Schubert CJ, Durisch-Kaiser E, Wehrli B, Thamdrup B, Lam P, Kuypers MMM (2006) Anaerobic ammonium oxidation in a tropical freshwater system (Lake Tanganyika). Environ Microbiol 8:1857-1863

Seitzinger SP (1988) Denitrification in freshwater and coastal marine ecosystems: ecological and geochemical significance. Limnol Oceanogr 33:702-724

Seitzinger SP, Kroeze C, Bouwman AF, Caraco N, Dentener F, Styles RV (2002) Global patterns of dissolved inorganic and particulate nitrogen inputs to coastal systems: recent conditions and future projections. Estuaries 25:640-655

> Seitzinger S, Harrison JA, Böhlke JK, Bouwmann AF and others (2006) Denitrification across landscapes and waterscapes: a synthesis. Ecol Appl 16:2064-2090

- Solorzano L (1969) Determination of ammonia in natural waters by the phenolhypochlorite method. Limnol Oceanogr 14:799-801

Steingruber SM, Friedrich J, Gächter R, Wehrli B (2001) Measurement of denitrification in sediments with the ${ }^{15} \mathrm{~N}$ isotope pairing technique. Appl Environ Microbiol 67: 3771-3778

Strauss EA, Lamberti GA (2000) Regulation of nitrification in aquatic sediments by organic carbon. Limnol Oceanogr 45:1854-1859

- Thamdrup B, Dalsgaard T (2002) Production of $\mathrm{N}_{2}$ through anaerobic ammonium oxidation coupled to nitrate reduction in marine sediments. Appl Environ Microbiol 68: $1312-1318$

> Tiirola MA, Rissanen AJ, Sarpakunnas M, Arvola L, Nykänen H (2011) Stable isotope profiles of nitrogen gas indicate denitrification in oxygen-stratified humic lakes. Rapid Commun Mass Spectrom 25:1497-1502

Trimmer M, Risgaard-Petersen N, Nicholls JC, Engström P (2006) Direct measurement of anaerobic ammonium oxidation (anammox) and denitrification in intact sediment cores. Mar Ecol Prog Ser 326:37-47

Wallenstein MD, Myrold DD, Firestone M, Voytek M (2006) Environmental controls on denitrifying communities and denitrification rates: insights from molecular methods. Ecol Appl 16:2143-2152

Wertz S, Dandie CE, Goyer C, Trevors JT, Patten CL (2009) Diversity of nirK denitrifying genes and transcripts in an agricultural soil. Appl Environ Microbiol 75:7365-7377

Wolsing M, Priemé A (2004) Observation of high seasonal variation in community structure of denitrifying bacteria in arable soil receiving artificial fertilizer and cattle manure by determining T-RFLP of nir gene fragments. FEMS Microbiol Ecol 48:261-271

> Wood ED, Armstrong FA, Richards FA (1967) Determination of nitrate in sea water by cadmium-copper reduction to nitrite. J Mar Biol Assoc UK 47:23-31

- Wu L, Kellogg L, Devol AH, Tiedje JM, Zhou J (2008) Microarray-based characterization of microbial community functional structure and heterogeneity in marine sediments from the Gulf of Mexico. Appl Environ Microbiol 74:4516-4529

- Yoshinaga I, Amano T, Yamagishi T, Okada K, Ueda S, Sako Y, Suwa Y (2011) Distribution and diversity of anaerobic ammonium oxidation (anammox) bacteria in the sediment of a eutrophic freshwater lake, Lake Kitaura, Japan. Microbes Environ 26:189-197

Editorial responsibility: Tom Battin,

Vienna, Austria
Submitted: May 14, 2012; Accepted: January 29, 2013 Proofs received from author(s): March 26, 2013 